\title{
Hálózati struktúra és nem teljes információ egy monopolisztikus versenyre épülő modellben
}

\begin{abstract}
A tanulmányban egy olyan modellt ismertetünk, amelyben a piaci szereplők nem teljes informáltságát hálózati megközelítéssel modellezzük. Ennek érdekében egy monopolisztikus versenyen alapuló, egyszerü makromodellbe vezetjük be a piaci hálózatot, majd ennek segítségével elemezzük a hálózati struktúra és az aggregált teljesítmény összefüggését. Azt találjuk, hogy a hálózat nemteljessége jóléti veszteséget okoz azáltal, hogy felerősíti a szereplők monopolerejét, ám ezt részben ellensúlyozhatja a szereplők heterogén termelékenysége, amennyiben a magasabb termelékenységü szereplők a centrálisabbak a hálózatban. Általánosságban az látszik, hogy a hálózat tökéletlensége erősíti a piac monopolisztikus és gyengíti annak versenyző jellegét, vagyis a monopolpiac irányába tolja el a piaci struktúrát.* Journal of Economic Literature (JEL) kód: D43, D52, L13, L14.
\end{abstract}

\section{Bevezetés}

A modern közgazdasági modellek számos tényezőjükben eltérnek a Walras-féle árverező paradigmáján nyugvó, tökéletes piacokat feltételező egyensúlyi modellektől (lásd Arrow-Debreu [1954]), hiszen azok jellemzően monopolisztikusan versenyzö piacokat, ragadós árakat és béreket, illetve egyéb piaci súrlódásokat (például hitelés likviditási korlátokat) feltételeznek. Ennek ellenére a legtöbb modell még mindig a racionálisan viselkedő szereplök tökéletes informáltságát feltételezi (Angeletos-Lian [2016]). A döntéshozók számára nem jelent akadályt (költséget vagy időt) az információkhoz való hozzáférés.

* A kutatást az Innovációs és Technológiai Minisztérium Felsőoktatási Intézményi Kiválósági Programja finanszírozta a Pécsi Tudományegyetem 4., „A hazai vállalatok szerepének növelése a nemzet újraiparosításában" tématerületi programja keretében.

Longauer Dóra, Pécsi Tudományegyetem Közgazdaságtudományi Kar, Regionális Politika és Gazdaságtan Doktori Iskola (e-mail: longauerd@ktk.pte.hu).

Sebestyén Tamás, Pécsi Tudományegyetem Közgazdaságtudományi Kar, Közgazdaságtan és Ökonometria Intézet és MTA-PTE Innováció és Gazdasági Növekedés Kutatócsoport (e-mail: sebestyent@ ktk.pte.hu).

A kézirat első változata 2018. október 18-án érkezett szerkesztőségünkbe.

DOI: http://dx.doi.org/10.18414/KSZ.2019.12.1257 
A valódi piacokra sokkal inkább az a jellemző, hogy az információk szétszóródnak, az egyes szereplők számára csak korlátozottan és eltérő minőségben érhetők el. Erre Hayek [1945] is felhívta a figyelmet, aki szerint az információ koncentrált formában sohasem létezik, hanem csak az egyének között szétszórt, részleges, sokszor egymásnak ellentmondó ismeretek formájában. Emiatt azt javasolja a közgazdászoknak, hogy a megoldást olyan egyének egymásra hatásából keressék, akik közül mindegyik csak részleges információval rendelkezik.

A tökéletes információ helyett a tökéletlen információ feltevésének észszerüségét több elmélet is alátámasztja. Sims [2003], [2010] racionálisfigyelmetlenségelmélete (rational inattention theory) alapján egy optimálisan viselkedő döntéshozó számára az információk költségvonzata miatt (legyen az materiális vagy kognitív) racionális lehet részleges információk alapján dönteni. Ebben a megközelítésben a teljes informáltság a túl magas információs költség miatt hasznosságveszteséggel járhat, és így irracionálisnak bizonyulhat. Reis [2006a], [2006b] elméletében az információfeldolgozás költségei mellett annak időigényességét is hangsúlyozza. Hosszú idő, amíg az új információ a feldolgozása során döntéshozatalhoz felhasználható állapotba kerül, emiatt a döntések gyakran hiányos vagy elavult információk alapján születnek meg. Az információ anyagi, mentális és időbeli költségei mellett a hiányos informáltság másik triviális oka a térbeliségből fakad. Az információáramlásnak és az elérhető információk körének korlátot szab a térbeli meghatározottság (Lucas [1972], Barro [1976]). Ha a térbeli korlátok miatt a vevők nem ismernek minden eladót, akkor még homogén termékek esetén is nagy különbségek adódhatnak a piaci árakban, ahogy azt a statisztikai adatok is alátámasztják (Stigler [1961], Marvel [1976]). Mindez felveti a nem teljes informáltság makroegyensúlyi következményeinek kérdését.

A nem teljes információ feltevését Lucas [1972], [1973], [1975] alkalmazta elsőként egy makroökonómiai modellben. Ebben a modellben még tökéletes versenypiacot feltételezett, és az úgynevezett szigetparadigmát használta a részleges információ modellezésére (lásd Phelps [1970]). Ez alapján a szereplők ismerik a helyi piaci árakat (az eladandó termékek árát), de nem ismerik a többi piacon - a többi szigeten - érvényes árakat (a vásárolt termékek árát). Mivel a szereplők még azelőtt döntenek, hogy megismernék a tényleges árakat, várakozásokat alkotnak az átlagos árindex nagyságáról. Emiatt a monetáris sokkoknak a rugalmas áralkalmazkodás ellenére is reálhatásuk lesz.

Lucas modellje a megjelenését követő évtizedekben számos modellt inspirált, amelyek a szereplők részleges informáltságát feltételezik. Ezek a modellek jellemzően azt vizsgálták, hogy hogyan befolyásolja az információk tökéletlensége a makrogazdaság müködését és az aggregált árak alakulását. Így például Townsend [1983] megmutatta, hogy a tökéletlen informáltság miatt a szereplők eltérő várakozásokat alakítanak ki, ami hatással van a gazdaság dinamikus müködésére. Sőt Woodford [2002] egy Lucas [1972]-höz nagyon hasonló nem teljes információs modellel tartós reálgazdasági hatásokat jelzett elöre. Ehhez mindössze két feltételezést változtatott meg az eredeti modellben: egyrészt monopolisztikusan versenyzői piacokat feltételezett (ami miatt az egyéni árdöntések már nem függetlenek többé), másrészt az ágensek nemcsak 
az árakkal kapcsolatban bizonytalanok, de az aktuális gazdasági helyzetről is csak várakozásaik vannak. Amennyiben az árdöntésnél a stratégiai komplementaritások elegendően erősen müködnek, egy nominális sokk hatása jelentős és tartós lehet. Mankiw-Reis [2002] még tovább ment, és a modern makroökonómia legfontosabb összefüggését, a ragadós árakon alapuló, újkeynesi Phillips-görbét a tökéletlen informáltságon alapuló ragadós információs Phillips-görbével helyettesítette. Ezáltal egy monetáris sokk hatása az inflációban szintén késleltetve mutatkozik meg, ami fontos szempontot vet fel az optimális monetáris politika tervezése kapcsán. L’Huillier [2012] a tökéletlen informáltság feltételezését a fogyasztók oldalán alkalmazta, és megmutatta, hogy ebben az esetben is lehetséges a monetáris politikai sokkok tartós reálgazdasági hatása. A nem teljes információ makroökonómiai alkalmazásairól részletes áttekintést ad Mankiw-Reis [2010], illetve Angeletos-Lian [2016].

A nem teljes informáltságot feltételező makrogazdasági modellekben közös, hogy a korlátozott informáltságnak egy aggregált, mindenkire egységesen vonatkozó mértékét feltételezik. Bár ezek a modellek jelentős mértékben hozzájárultak ahhoz, hogy jobban megértsük a gazdasági rendszer müködését, ugyanakkor e lényegi egyszerüsítés miatt a modellek nem képesek megragadni az információeloszlás egyenlőtlenségeit. Ahhoz, hogy az informáltságban meglevő heterogenitást is figyelembe tudjuk venni, egy olyan megközelítésre van szükség, amely lehetővé teszi a piaci szereplők közötti hálózatosodás megfelelő modellezését. A problémára a hálózatelmélet nyújthat egy lehetséges megoldást. A szereplők hálózatban való modellezése azt eredményezi, hogy a hálózatban elfoglalt pozíció meghatározza a rendelkezésre álló információk körét, vagyis a hálózatban való döntéshozatalból természetes módon következik a szereplők tökéletlen informáltsága. Emiatt az információk eloszlása a hálózati struktúrától függően igencsak változatos lehet.

A hálózatok tudománya jelentős fejlődésen ment keresztül az elmúlt két évtizedben. Egyrészt kiderült, hogy a megfigyelt hálózati rendszerek nagyon hasonló szerkezetekkel jellemezhetők (Barabási-Albert [1999], Barabási [2016]). Ugyanakkor az is kiderült, hogy egy komplex rendszer teljesítményét nagymértékben befolyásolja az, hogy az elemei milyen módon kapcsolódnak egymáshoz (Jackson-Wolinsky [1996], Bala-Goyal [2000], Barabási [2016]). Különösen fontos annak felismerése, hogy a kapcsolódási szerkezet szorosan összefügg a vizsgált hálózati rendszer hatékonyságával és stabilitásával (Granovetter [1973], [1985], Csermely [2005], Mérő [2014]). Ezek az eredmények arra engednek következtetni, hogy a gazdaság aggregált müködésében jelentős szerepe van annak, hogy miként kapcsolódnak egymáshoz a gazdasági szereplők.

Erre a megfontolásra építve ebben a tanulmányban egy olyan modellt mutatunk be, amelyben a tökéletlen informáltságot a piaci hálózat közvetíti. Az újdonság a megszokott gazdaságmodellezési paradigmához képest tehát az, hogy a piacra úgy tekintünk, mint egy (a piac keresleti és kínálati oldalán levő) gazdasági szereplök alkotta hálózatra. Ennek érdekében Dixit-Stiglitz [1977] monopolisztikusan versenyző modelljébe építjük be a fogyasztók és termelők közötti hálózatot, majd erre alapozva Gali [2008] alapján levezetünk egy egyszerủ makromodellt. A hálózati megközelítés új kontextusba helyezi a vizsgált kérdéseket, relevánssá válik ugyanis a hálózati struktúra szerepe a makroegyensúlyi folyamatokban. 
A tanulmány felépítése a következő. Először a Dixit-Stiglitz-féle monopolisztikus versenymodellbe építünk be explicit hálózati szerkezetet az eladók és vevők - mint hálózati csúcsok - között. A tanulmány további részeiben erre az alapmodellre építve vizsgálunk egy egyszerü egyensúlyi makromodellt. A modellnek háromféle esetét mutatjuk be, a legspecifikusabbtól haladva a legáltalánosabb esetig. Elsőként egy reprezentatív szereplős változatot ismertetünk, amelyben egyetlen paraméterrel tudjuk leírni a hálózati szerkezetet. Az ezt követő részben kétféle szereplő feltételezése lehetővé teszi összetettebb hálózati szerkezetek elemzését is. Végül tetszőleges számú vállalat esetén mutatjuk be a modell múködését, amellyel már a fokszámeloszlás szerepét is vizsgálni tudjuk. A tanulmányt összefoglalás zárja.

\section{Hálózat a monopolisztikus verseny piaci modelljében}

A következőkben Dixit-Stiglitz [1977] monopolisztikus piaci modelljét ismertetjük hálózati kontextusba ágyazva. A modellben minden szereplő kétféle minőségben van jelen, egyrészt úgy, mint fogyasztó (háztartás), másrészt úgy, mint termelő (vállalat). ${ }^{1}$ Elsőként a szereplök keresleti, majd pedig a kínálati döntését mutatjuk be, különös hangsúlyt fektetve a hálózati vonatkozásokra.

\section{Keresleti döntések}

Legyen $\mathbf{N}=\{1, \ldots, N\}$ a szereplők halmaza, amiről tegyük fel, hogy véges számú és legalább egyelemü, vagyis $N \geq 1$. Értelmezzük a szereplők közötti kapcsolati hálót a következőképp:

$S=\left(s_{i j}\right)_{i, j \in \mathbf{N}}$,

ahol

$s_{i j}= \begin{cases}1, & \text { ha az } i \text {-edik szereplő fogyasztja a } j \text {-edik szereplő termékét, } \\ 0, & \text { különben. }\end{cases}$

A mátrix $s_{i j}$ eleme tehát azt mutatja meg, hogy az $i$-edik fogyasztó és a j-edik termelö között van-e kapcsolat.

Az így definiált kapcsolati háló mellett az i-edik szereplő kompozit fogyasztását $\left(C_{i}\right.$-vel jelölve) a következő CES-aggregátor határozza meg (Dixit-Stiglitz [1977]):

\footnotetext{
${ }^{1}$ A feltevés mögött elsősorban az a gyakorlati ok áll, hogy lényegesen leegyszerűsíti a modellezett hálózatot. Kétféle szereplő feltételezésével ugyanis úgynevezett páros gráfokkal kellene dolgoznunk, amelyekre nehezebben alkalmazhatók a hálózatelméleti módszerek. Az optimális döntések eredményénél nincs jelentősége annak, ha a fogyasztói és a termelői döntéseket külön-külön vagy pedig szimultán kezeljük, hiszen a fogyasztói döntésnél az árakat (a termelői döntések eredményét), a termelői döntésnél pedig a keresleti függvényeket (a fogyasztói döntések eredményét) tekintjük adottnak.
} 
$C_{i, t}=\left(\sum_{j=1}^{N_{t}} s_{i j, t} c_{i j, t}^{\frac{\varepsilon-1}{\varepsilon}}\right)^{\frac{\varepsilon}{\varepsilon-1}}$,

ahol $c_{i j, t}$ jelöli az $i$-edik szereplö fogyasztását a $j$-edik differenciált termékből a $t$-edik periódusban, $\varepsilon$ pedig a termékek közötti helyettesítés rugalmasságát fejezi ki. A paraméter egységnyinél nagyobb értékeket vehet fel, és minél nagyobb ez az érték, annál könnyebb a helyettesítés a termékek között $(\varepsilon \rightarrow \infty$ esetén tökéletesen helyettesítő viszonyról van szó). ${ }^{2}$

A cél, hogy ez a kompozit fogyasztás adott költségvetési keret mellett minél nagyobb szintű legyen. Az i-edik szereplő tehát a következő optimalizálási problémával néz szembe:

$\max _{c_{i j, t}} C_{i, t}=\left(\sum_{j=1}^{N_{t}} s_{i j, t} c_{i j, t}^{\frac{\varepsilon-1}{\varepsilon}}\right)^{\frac{\varepsilon}{\varepsilon-1}}$,

s.t. $z_{i, t}=\sum_{j=1}^{N_{t}} p_{j, t} c_{i j, t}$,

ahol $p_{j, t}$ a j-edik termék ára a $t$-edik periódusban. Jól látszik, hogy amennyiben a vizsgált fogyasztó nincs kapcsolatban valamely $j$-edik termelövel $\left(s_{i j, t}=0\right)$, akkor annak terméke iránt nem fog keresletet támasztani, hiszen a kompozit fogyasztását ez nem növelné, ellenben többletköltséggel járna.

A szélsőérték-feladat megoldásaként megkapjuk az $i$-edik szereplő $j$-edik termék iránti egyéni keresleti függvényét:

$c_{i j, t}=s_{i j, t} C_{i, t}\left(\frac{p_{j, t}}{P_{i, t}^{H}}\right)^{-\varepsilon}$,

ahol $P_{i, t}^{H}$ a $C_{i, t}$ kompozit fogyasztói kosárra vonatkozó árindex az alábbiaknak megfelelően: ${ }^{3}$

$P_{i, t}^{H}=\left(\sum_{j=1}^{N_{t}} s_{i j, t} p_{j, t}^{1-\varepsilon}\right)^{\frac{1}{1-\varepsilon}}$.

A keresleti függvényt megvizsgálva az látszik, hogy az egyes termékkategóriák kereslete kifejezhető a termék ára $\left(p_{j, t}\right)$, a kompozit fogyasztás $\left(C_{i, t}\right)$, valamint egy árindex segítségével $\left(P_{i, t}^{H}\right)$, amelyre ezentúl érzékelt árindexként fogunk hivatkozni, utalva arra, hogy egyedi változóról van szó. Ez azt jelenti, hogy az egyes keresleteket a hálózati struktúra befolyásolni fogja, hiszen az érzékelt árindex függ az adott szereplő hálózati beágyazottságától.

${ }^{2} \mathrm{Az} 1 /(\varepsilon-1)$ kifejezés a változatosság iránti preferenciát (preference for diversity) határozza meg (lásd Benassy [1996]). Minél nagyobb a kifejezés értéke (minél közelebb van $\varepsilon 1$-hez), annál fontosabb a fogyasztó számára a változatosság.

${ }^{3}$ Az optimalizálási feladat levezetése megtalálható a tanulmány végén, a Függelékben. 


\section{Kinálati döntések}

Monopolisztikus piacon a termelők érzékelik a termékük iránti keresletet, vagyis ismerik a (2) keresleti függvényeket. A j-edik szereplő terméke iránt támasztott összes kereslet ekkor az alábbi:

$\sum_{i=1}^{N_{t}} c_{i j, t}=\sum_{i=1}^{N_{t}} s_{i j, t} C_{i, t}\left(\frac{p_{j, t}}{P_{i, t}^{H}}\right)^{-\varepsilon}=p_{j, t}^{-\varepsilon} \sum_{i=1}^{N_{t}} s_{i j, t} C_{i, t} P_{i, t}^{H^{\varepsilon}}$.

A $j$-edik vállalat termelése a felhasznált munkaerő függvénye:

$y_{j, t}=A_{j, t} l_{j, t}^{1-\alpha}$,

ahol $1-\alpha$ a munkaerőre vonatkozó termelési rugalmasság, $y_{j, t} A_{j, t}$ és $l_{j, t}$ pedig a $j$-edik vállalat termelése, termelékenysége, illetve munkaerő-felhasználása a $t$-edik periódusban. A j-edik vállalat célja, hogy a termékével szemben támasztott kereslet mellett a lehető legnagyobb profitot érje el, vagyis a következő optimalizálási problémával néz szembe:

$$
\begin{aligned}
& \max _{p_{j, t}} \Pi_{j, t}=p_{j, t} y_{j, t}-T C_{j, t}\left(y_{j, t}\right), \\
& \text { s.t. } y_{j, t}=p_{j, t}^{-\varepsilon} \sum_{i=1}^{N_{t}} s_{i j, t} C_{i, t} P_{i, t}^{H^{\varepsilon}},
\end{aligned}
$$

ahol $T C_{j, t}(\cdot)$ a (termelési technológiától függö) teljes termelési költséget jelöli. A feladat megoldásaként megkapjuk a j-edik termék optimális árát: ${ }^{4}$

$p_{j, t}=\frac{\varepsilon}{\varepsilon-1} M C_{j, t}=\frac{\varepsilon}{\varepsilon-1} \frac{W_{t}}{(1-\alpha) A_{j, t}} l_{j, t}^{\alpha}$,

ahol $M C_{j, t}$ a j-edik termékre vonatkozó reálhatárköltség. A monopolisztikusan versenyző vállalat egy $\varepsilon$-tól függő haszonkulcsot alkalmaz a határköltségen felül, amely annál nagyobb, minél tökéletlenebb helyettesítői egymásnak a termékek (minél kisebb az $\varepsilon$ ). Ha a vállalat teljes költsége a termelésnek nem lineáris függvénye, akkor az árdöntést érinteni fogja a piaci hálózat nemteljessége. Ebben az esetben ugyanis a határköltség függ a termelés nagyságától, amelyet viszont a kereslet nagysága határoz meg, és így a hálózati szerkezet végső soron befolyásolni fogja az egyes árakat.

\section{A homogén vállalat esete}

Az alábbiakban a legspeciálisabb, kapcsolatszám (fokszám) szempontjából homogén vállalatokat feltételező modell egyensúlyi összefüggéseit vezetjük le. Ez azt jelenti, hogy az egyes szereplőkről feltesszük, hogy mind fogyasztói, mind termelői minőségükben reprezentatívak. A hálózat szempontjából ez azt jelenti, hogy minden szereplőnek

\footnotetext{
${ }^{4}$ A levezetés a Függelékben megtalálható.
} 
ugyanannyi kapcsolata van. Jelöljük a hálózat sürüségét $d$-vel. ${ }^{5}$ Ekkor minden egyes szereplőre igaz, hogy az összes szereplő $d$ hányadával van kapcsolatban, vagyis $N d$ számú terméket fogyaszt, illetve ugyanennyi szereplő támaszt keresletet a terméke iránt.

\section{Aggregált kibocsátás homogén vállalatok esetén}

A kibocsátás egyensúlyi értékének levezetéséhez írjuk fel a reprezentatív vállalat termékére vonatkozó egyensúlyi feltételt a (2) keresleti függvények segítségével:

$y_{t}=\sum_{i=1}^{N_{t}} c_{i j, t}=\sum_{i=1}^{N_{t}} s_{i j, t} C_{i, t}\left(\frac{p_{j, t}}{P_{i, t}^{H}}\right)^{-\varepsilon}=N_{t} d_{t} \frac{C_{t}}{N_{t}}\left(\frac{p_{t}}{P_{t}^{H}}\right)^{-\varepsilon}=d_{t} C_{t}\left(\frac{p_{t}}{P_{t}^{H}}\right)^{-\varepsilon}$,

ahol $y_{t}$, illetve $p_{t}$ a reprezentatív vállalat termékének kínálata, illetve ára, $P_{i, t}^{H}$ pedig a reprezentatív háztartásra vonatkozó érzékelt árindex. Az egyensúlyi feltételben kihasználtuk, hogy a termelö $N_{t} d_{t}$ fogyasztóval van kapcsolatban, illetve azt, hogy reprezentatív háztartásokra $C_{i, t}=C_{t} / N_{t}$. Aggregált szinten a gazdaság egyensúlyát a kompozit termék keresletének és kínálatának egyensúlya fejezi ki, azaz $Y_{t}=C_{t}$, ahol $Y_{t}$-vel a makrogazdasági kibocsátást jelöljük. Behelyettesítve ezt az előbbi feltételbe, megkapjuk, hogy milyen összefüggés van a reprezentatív szereplö termelése és a makrogazdasági kibocsátás között:

$y_{t}=d_{t} Y_{t}\left(\frac{p_{t}}{P_{t}^{H}}\right)^{-\varepsilon}$.

Legyen a munkakínálat fix és egységnyi! A munkapiac egyensúlyi feltételét fel tudjuk írni a (4) és (6) összefüggések segítségével a következőképpen:

$1=N_{t} l_{t}=N_{t}\left(\frac{y_{t}}{A_{t}}\right)^{\frac{1}{1-\alpha}}=N_{t}\left[\frac{d_{t} Y_{t}}{A_{t}}\left(\frac{p_{t}}{P_{t}^{H}}\right)^{-\varepsilon}\right]^{\frac{1}{1-\alpha}}=N_{t}\left(\frac{d_{t} Y_{t}}{A_{t}}\right)^{\frac{1}{1-\alpha}}\left(\frac{p_{t}}{P_{t}^{H}}\right)^{-\frac{\varepsilon}{1-\alpha}}$.

Elevenítsük fel az érzékelt árindex (3) szerinti összefüggését. Mivel egy reprezentatív fogyasztó $N_{t} d_{t}$ terméket fogyaszt, az összefüggés átírható az alábbiak szerint:

$P_{t}^{H}=\left(\sum_{j=1}^{N_{t}} s_{i j, t} p_{j, t}^{1-\varepsilon}\right)^{\frac{1}{1-\varepsilon}}=\left(N_{t} d_{t} p_{t}^{1-\varepsilon}\right)^{\frac{1}{1-\varepsilon}}=\left(N_{t} d_{t}\right)^{\frac{1}{1-\varepsilon}} p_{t}$.

Használjuk fel ez utóbbit a munkapiac egyensúlyára vonatkozó összefüggésben:

$$
\begin{aligned}
& 1=N_{t}\left(\frac{d_{t} Y_{t}}{A_{t}}\right)^{\frac{1}{1-\alpha}}\left[\frac{p_{t}}{\left(N_{t} d_{t}\right)^{\frac{1}{1-\varepsilon}} p_{t}}\right]^{-\frac{\varepsilon}{1-\alpha}}=N_{t}\left(\frac{d_{t} Y_{t}}{A_{t}}\right)^{\frac{1}{1-\alpha}}\left(N_{t} d_{t}\right)^{\frac{\varepsilon}{(1-\alpha)(1-\varepsilon)}}= \\
& =d_{t}^{\frac{1}{(1-\alpha)(1-\varepsilon)}} N_{t}^{\frac{1+\alpha(\varepsilon-1)}{(1-\alpha)(1-\varepsilon)}}\left(\frac{Y_{t}}{A_{t}}\right)^{\frac{1}{1-\alpha}} .
\end{aligned}
$$

${ }^{5}$ A hálózat sűrűsége a hálózatban létező kapcsolatok számának aránya az összes lehetséges kapcsolathoz viszonyítva. Ha például a hálózatban minden második kapcsolat létezik, akkor a hálózat sürűsége 0,5 . Ez alapján az üres hálózat sürűsége 0 , a teljes hálózat sűrüsége pedig 1 . 
Átrendezve az imént kapott kifejezést, megkapjuk a keresett összefüggést az aggregált outputra:

$Y_{t}=A_{t} d_{t}^{\frac{1}{\varepsilon-1}} N_{t}^{\frac{1+\alpha(\varepsilon-1)}{\varepsilon-1}}$

\section{A hálózati sürüség hatása}

A kapcsolatszámban homogén vállalatokat feltételező modell lehetőséget ad arra, hogy a hálózat hatását egy paraméteren (a $d$ sűrüségi paraméter) keresztül vizsgálhassuk. Alkalmazzuk az $N_{t}=1$ egyszerüsítést (ez gyakorlatilag a szereplők számának 1-re történő normálása), legyen továbbá $A_{t}=1$ minden $t$-re. Ekkor a (7) összefüggés leegyszerüsödik:

$Y_{t}=d_{t}^{\frac{1}{\varepsilon-1}}$.

Az output nagysága a hálózat sủrüségének, valamint a helyettesítés rugalmasságának a függvénye. Az 1. ábra a kibocsátás alakulását mutatja a hálózat sürüségének függvényében, különböző helyettesítési rugalmasságokat feltételezve. ${ }^{6}$

\section{1. ábra}

Az aggregált kibocsátás a piaci hálózat sürüségének függvényében a helyettesítési rugalmasság különböző értékeire

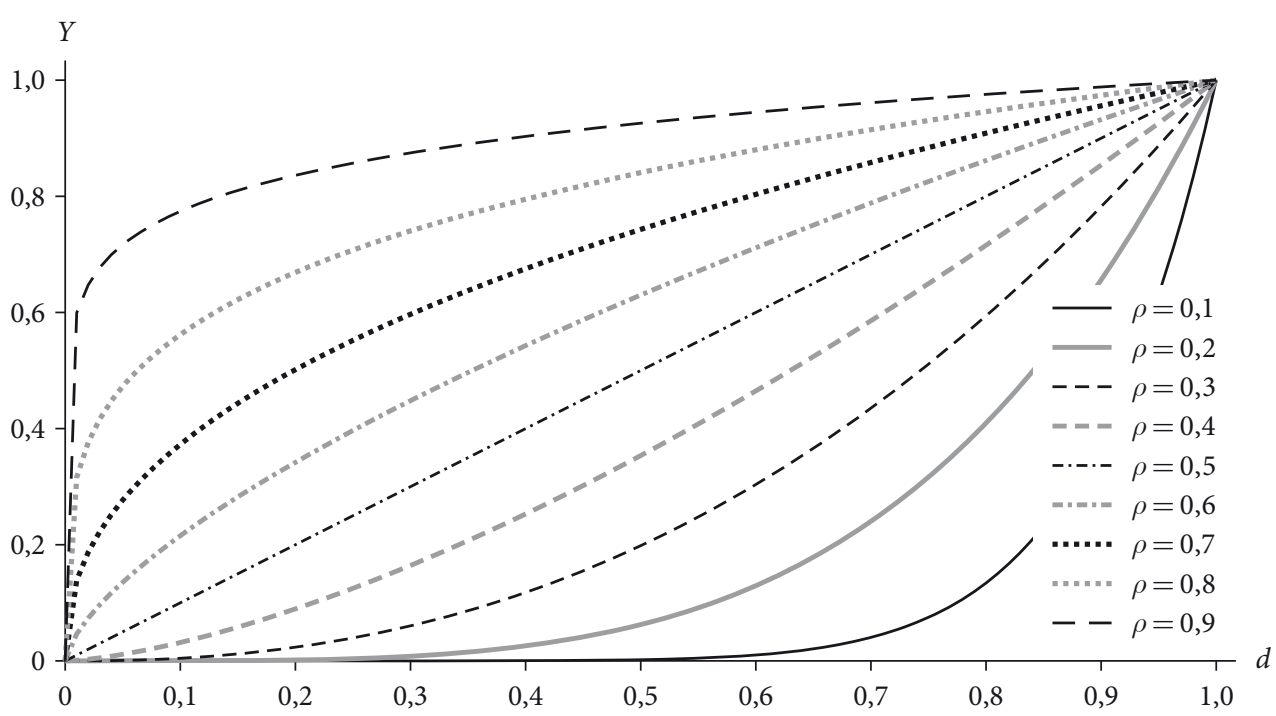

${ }^{6}$ Monopolisztikus versenypiacon a helyettesítés rugalmassága egységnyinél nagyobb. Az $\varepsilon$-t ekkor fel tudjuk írni egy 0 és 1 közötti paraméter segítségével: $\varepsilon=1 /(1-\rho)$, ahol annál nagyobb $\varepsilon$, minél nagyobb $\rho$. Ha $\rho \rightarrow 1$, akkor a helyettesítés tökéletes, míg $\rho=0$ mellett az alkalmazott skálán a helyettesítés a lehető legrugalmatlanabb. 
A felírás és az ábra alapján is belátható, hogy a hálózat ritkulása holtteher-veszteséget okoz: adott munkaerővel kisebb kibocsátást ér el a gazdaság. Úgy tűnik, mintha a hálózat teljesebbé válásával a rendelkezésre álló erőforrásokat a gazdaság egyre hatékonyabban tudná felhasználni a végső kibocsátás előállításában. Mivel a hálózati sürüségre a szereplők informáltságának mértékeként is tekinthetünk, ez az eredmény úgy is értelmezhető, hogy az alacsonyabb informáltság aggregált szinten magasabb holtteher-veszteséggel jár. Ez a jelenség két hatás eredőjeként áll össze.

Egyrészt, a hálózat ritkulásakor a változatosságból származó extern hatás mértéke csökken. Minél kevesebb vállalatot ismer a reprezentatív háztartás, annál kevesebbfajta terméket tud fogyasztani, és annál kisebb lesz az abból származó hasznossága is. A hálózati szerkezet hatása a mikro- és makroszint közötti átmenet során jelenik meg: a hálózat sűrűbbé válásakor egyre erőteljesebben érvényesül a sokféleség extern hatása. Ennek fényében logikus, hogy a helyettesítés rugalmassága befolyásolja a hálózati hatást. Magas rugalmasság (1-hez közeli $\rho$-érték) esetén a sokféleségből eredő extern hatás eleve kisebb, hiszen a termékek erös helyettesíthetősége a sokféleség értékét csökkenti. Ekkor a hálózati hatás relatíve gyenge, relatíve alacsony sűrüség mellett érződik az imént vázolt holtteher-veszteség. Alacsony rugalmasság mellett lényegesen erősebb a $d$ hatása, mivel ekkor a sokféleségből eredő extern hatás erős, így a kapcsolatok ritkulásából fakadó elvesztett sokféleség már relatíve sürü hálózati szerkezet mellett is nagyobb holtteher-veszteséget generál. Végső soron tehát a hálózati szerkezet jelentősége elsősorban akkor jelentkezik, ha a termelök monopolereje a helyettesíthetőség alacsony rugalmassága miatt magas.

A hálózat ritkulásából fakadó holtteher-veszteség másik oka az, hogy a szereplők közötti kapcsolatok ritkulásával tulajdonképpen a monopolerő növekszik: egy vállalat monopolereje egy adott fogyasztóval szemben nyilván annál nagyobb, minél kevesebb versenytárssal áll kapcsolatban az adott vevő. Minél ritkább tehát a hálózat, annál kisebb ez a verseny átlagosan, ami a monopolerő növekedésével és végső soron holtteher-veszteség keletkezésével jár. Ez a hatás is összefügg a helyettesíthetöséggel: alacsony szintű helyettesíthetőség esetén a termelők monopolereje eleve nagy, erre épül rá a kapcsolatok ritkaságából következö, addicionális monopolhatás. Magas helyettesíthetőség mellett a hálózati szerkezet jelentősebb ritkulása szükséges a holtteher-veszteség azonos mértékének előidézéséhez.

Fontos azt is megjegyeznünk, hogy a modell speciális esetében, egészen pontosan $d=1$ mellett az eredeti, hálózatot nem feltételező modell eredményét kapjuk vissza: ekkor ugyanis teljes kapcsoltságot feltételezünk, amely a szokásos modellfelírás implicit feltevése.

Összefoglalva az eredményeket, azt látjuk a modellnek ebben a nagyon egyszerü változatában, hogy az információk elérhetősége befolyásolja a makrogazdasági egyensúlyt, ugyanakkor a hatások elsősorban korlátozott helyettesíthetőség esetén, vagyis monopolisztikus piacokon érvényesülnek. 


\section{A kétféle típusú vállalat esete}

Az eddigiek során nagyon egyszerűen, mindössze egy paraméteren keresztül modelleztük a szereplők nem teljes informáltságát: a $d$ hálózati paraméter a hálózat sürüségét fejezte ki. A következőkben továbblépünk ezen az egyszerü megközelítésen, és fokszám tekintetében kétféle vállalatot feltételezünk. A szereplők háztartási minőségükben továbbra is reprezentatívak, ugyanakkor mint termelők különbséget teszünk közöttük a hálózati fokszám alapján. Mint látni fogjuk, ez a megközelítés már alkalmas lesz arra, hogy összetettebb hálózati struktúrákat is elemezzünk.

\section{Aggregált kibocsátás kétféle típusú vállalatra}

Tegyük fel, hogy a gazdaságban fokszám tekintetében kétféle vállalat müködik. Jelöljük az 1-es típusú vállalatok arányát $a_{t}$-vel, ekkor 1-es típusú vállalatból összesen $a_{t} N$, míg 2-es típusúból $\left(1-a_{t}\right) N_{t}$ létezik. Legyen a kétféle vállalatra $d_{1, t}$ illetve $d_{2, t}$ a vonatkozó sürüségi paraméter (a saját fokszám aránya az összes lehetséges kapcsolathoz viszonyítva). Ekkor az 1-es típusú vállalat fokszáma $N_{t} d_{1, t}$, a 2-es típusú vállalat fokszáma pedig $N_{t} d_{2, t}$ vagyis ennyi szereplő ismeri és fogyasztja az adott típusú vállalat termékét. A szereplők továbbra is reprezentatívak fogyasztási minőségükben, ami egyúttal azt is jelenti, hogy a kapcsolatok egyenletes eloszlása esetén egy fogyasztó most $a_{t} N d_{1} 1$-es, míg $\left(1-a_{t}\right) N d_{2} 2$-es típusú vállalat termékét fogyasztja.

Ebben a modellben kétféle típusú vállalat működik, így a termelési függvényük is különbözni fog. Legyen $y_{1, t}=A_{1, t} l_{1, t}^{1-\alpha}$, illetve $y_{2, t}=A_{2, t} l_{2, t}^{1-\alpha}$ az első, illetve a második típusú vállalat termelési függvénye. A $t$-edik periódusban az optimális árak ekkor:

$p_{1, t}=\frac{\varepsilon}{\varepsilon-1} \frac{W_{t} l_{1, t}^{\alpha}}{(1-\alpha) A_{1, t}}$,

$p_{2, t}=\frac{\varepsilon}{\varepsilon-1} \frac{W_{t} l_{2, t}^{\alpha}}{(1-\alpha) A_{2, t}}$.

Írjuk fel ezek segítségével a termékpiaci egyensúlyi feltételeket:

$$
\begin{aligned}
& A_{1, t} l_{1, t}^{1-\alpha}=N_{t} d_{1, t} \frac{C_{t}}{N_{t}}\left(\frac{p_{1, t}}{P_{t}^{H}}\right)^{-\varepsilon}=d_{1, t} \frac{C_{t}}{P_{t}^{H^{-\varepsilon}}}\left(\frac{\varepsilon}{\varepsilon-1}\right)^{-\varepsilon}\left[\frac{W_{t} l_{1, t}^{\alpha}}{(1-\alpha) A_{1, t}}\right]^{-\varepsilon}, \\
& A_{2, t} l_{2, t}^{1-\alpha}=N_{t} d_{2, t} \frac{C_{t}}{N_{t}}\left(\frac{p_{2, t}}{P_{t}^{H}}\right)^{-\varepsilon}=d_{2, t} \frac{C_{t}}{P_{t}^{H^{-\varepsilon}}}\left(\frac{\varepsilon}{\varepsilon-1}\right)^{-\varepsilon}\left[\frac{W_{t} l_{2, t}^{\alpha}}{(1-\alpha) A_{2, t}}\right]^{-\varepsilon} .
\end{aligned}
$$

Elosztva a két egyensúlyi feltételt egymással, a (9) összefüggést kapjuk a kétféle típusú vállalat munkakeresletére:

$l_{2, t}=\left(\frac{d_{1, t}}{d_{2, t}}\right)^{-\frac{1}{1+\alpha(\varepsilon-1)}}\left(\frac{A_{1, t}}{A_{2, t}}\right)^{\frac{1-\varepsilon}{1+\alpha(\varepsilon-1)}} l_{1, t}$. 
Kombinálva ezt az egyensúlyi árakkal, a kétféle típusú vállalat optimális ára között a (10) összefüggés adódik:

$p_{2, t}=\left(\frac{d_{1, t}}{d_{2, t}}\right)^{-\frac{\alpha}{1+\alpha(\varepsilon-1)}}\left(\frac{A_{1, t}}{A_{2, t}}\right)^{\frac{1}{1+\alpha(\varepsilon-1)}} p_{1, t}$.

Ez utóbbi segítségével felírható a reprezentatív fogyasztó által érzékelt árindex az alábbiaknak megfelelöen:

$$
\begin{aligned}
& P_{t}^{H}=\left[a_{t} N_{t} d_{1, t} p_{1, t}{ }^{1-\varepsilon}+\left(1-a_{t}\right) N_{t} d_{2, t} p_{2, t}{ }^{1-\varepsilon}\right]^{\frac{1}{1-\varepsilon}}= \\
& =N_{t}^{\frac{1}{1-\varepsilon}}\left[a_{t} d_{1, t}+\left(1-a_{t}\right) d_{2, t}\left(\frac{d_{1, t}}{d_{2, t}}\right)^{\frac{\alpha(1-\varepsilon)}{1+\alpha(\varepsilon-1)}}\left(\frac{A_{1, t}}{A_{2, t}}\right)^{\frac{1-\varepsilon}{1+\alpha(\varepsilon-1)}}\right]^{\frac{1}{1-\varepsilon}} p_{1, t}=\left(N_{t} c_{t}\right)^{\frac{1}{1-\varepsilon}} p_{1, t},
\end{aligned}
$$

ahol felhasználtuk, hogy $a_{t}$, illetve $1-a_{t}$ az első, illetve a második típusú vállalat részaránya a $t$-edik periódusban. A levezetésnél az átláthatóság kedvéért bevezettük a $c_{t}$ jelölést, amely a kétféle típusú vállalat fokszámarányát, számarányát, továbbá termelékenységarányát tömörítő változó.

A makrogazdasági kibocsátás levezetéséhez írjuk fel a munkapiaci egyensúlyi feltételt (továbbra is fix munkakínálatot feltételezünk), majd használjuk ki benne 1. a termékpiaci egyensúlyi feltételeket, 2 . az árindexre kapott (11) összefüggést, végül pedig 3. az egyedi árak kapcsolatára vonatkozó (10) összefüggést. Ekkor a következőt kapjuk:

$$
1=\left(N_{t} \widehat{c}_{t}\right)^{\frac{1+\alpha(\varepsilon-1)}{(1-\alpha)(1-\varepsilon)}} Y_{t}^{\frac{1}{1-\alpha}}
$$

ahol bevezettük a $\widehat{c_{t}}$ kifejezést: $^{7}$

$\widehat{c_{t}}=a_{t} d_{1, t} \frac{1}{1+\alpha(\varepsilon-1)} A_{1, t}^{\frac{\varepsilon-1}{1+\alpha(\varepsilon-1)}}+\left(1-a_{t}\right) d_{2, t}{ }^{\frac{1}{1+\alpha(\varepsilon-1)}} A_{2, t}^{\frac{\varepsilon-1}{1+\alpha(\varepsilon-1)}}$.

A fenti kifejezés értelmezéséhez tekintsük az $A_{1, t}=A_{2, t}=1$ egyszerüsítést. Jól látható, hogy ebben az esetben $\widehat{c_{t}}$ a kétféle típusú vállalat kapcsolati sürüsége súlyozott átlagaként adódik, ahol a súlyok a kétféle típus részaránya a teljes populáción belül. Ez alapján $\widehat{c_{t}}$ egyfajta átlagos kapcsolódási valószínüséget/sürüséget mér. Ugyanakkor a kapcsolati sürűségek $\left(d_{1, t}\right.$ és $\left.d_{2, t}\right)$ nem lineárisan lépnek be az összefüggésbe: a kitevőt megvizsgálva könnyen látható, hogy a helyettesíthetőség növekedése csökkenti a kitevőt, így a hálózati struktúra szerepét (ahogy a korábbi levezetéseknél is láttuk), míg a korlátozottabb helyettesíthetőség a hálózati szerkezet erősebb szerepét mutatja.

Ha a technológiai koefficienseket is bekapcsoljuk, akkor az előbbi képet annyival árnyalhatjuk, hogy $\widehat{c_{t}}$ nem pusztán a kapcsolódási sürüségek, hanem a technológiai szinttel súlyozott kapcsolódási valószínűségek átlagaként adódik. Figyelembe veszi ugyanis a kétféle típusú vállalat technológiai különbségét:

$$
{ }^{7} \mathrm{~A} c_{t} \text {, illetve a } \widehat{c_{t}} \text { között a következö összefüggés érvényes: } \widehat{c_{t}}=c_{t} d_{1, t}^{\frac{\alpha(1-\varepsilon)}{1+\alpha(\varepsilon-1)}} A_{1, t}^{\frac{\varepsilon-1}{1+\alpha(\varepsilon-1)}} \text {. }
$$


produktívabb technológia nagyobb súlyt jelent, ugyanakkor ez a súly sem független a helyettesíthetőségtől.

A (12) összefüggést kifejezve $Y_{t}$-re, megkapjuk az aggregált kibocsátást a hálózati struktúra függvényében:

$Y_{t}=\left(N_{t} \widehat{c_{t}}\right)^{\frac{1+\alpha(\varepsilon-1)}{\varepsilon-1}}$.

Vegyük észre, hogy a $d_{1, t}=d_{2, t}=d_{t}$ és az $A_{1, t}=A_{2, t}=A_{t}$ behelyettesítéssel a (14) összefüggésbe, visszakapjuk az előző modellnél kapott eredményt.

\section{A hálózati struktúra szerepe}

Ha alkalmazzuk ezúttal is az $N=1$ normát, az aggregált kibocsátás leegyszerüsödik: $Y_{t}={\widehat{c_{t}}}^{\frac{1+\alpha(\varepsilon-1)}{\varepsilon-1}}$,

ahol $\widehat{c_{t}}=a_{t} d_{1, t}^{\frac{1}{1+\alpha(\varepsilon-1)}} A_{1, t}^{\frac{\varepsilon-1}{1+\alpha(\varepsilon-1)}}+\left(1-a_{t}\right) d_{2, t}^{\frac{1}{1+\alpha(\varepsilon-1)}} A_{2, t}^{\frac{\varepsilon-1}{1+\alpha(\varepsilon-1)}}$.

A modellben három hálózati mutató szerepel: $d_{1}$ az 1-es típusú vállalatok fokszáma, $d_{2, t}$ a 2-es típusú vállalatok fokszáma, valamint $a_{t}$ az 1-es típusú vállalatok gyakoriságát jelölő hálózati paraméter. ${ }^{8}$ Ez utóbbi azt fejezi ki, mekkora a valószínüsége annak, hogy egy véletlenszerüen kiválasztott vállalatnak éppen $d_{1, t}$ a fokszáma, vagyis fokszámgyakoriságként is hivatkozhatunk rá. Ezek együtt a reprezentatív vállalat speciális esetét feltételezö modellhez képest már bonyolultabb hálózati struktúrák vizsgálatát is lehetővé teszik.

A homogén vállalatos modellben láttuk, hogy a hálózat sürüsége jelentős hatást gyakorolt a gazdaság aggregált teljesítményére. Ez logikus, hiszen a hálózat sűrűsége az információk elérhetőségének mérőszámaként is értelmezhető. Ahhoz, hogy a hálózati struktúra szerepét a hálózati sűrűség hatásától függetlenül is vizsgálni tudjuk, ki kell szürnünk annak hatását. Ennek érdekében rögzítsük egy konstans értéken. A kétvállalatos modellben a teljes hálózat sürüségét úgy tudjuk kiszámolni, ha elosztjuk a létező kapcsolatok számát az összes lehetséges kapcsolat számával, vagyis a következö összefüggés alapján (elhagyva a $t$ idöindexet):

$\bar{d}=\frac{N\left[a N d_{1}+(1-a) N d_{2}\right]}{N^{2}}=a d_{1}+(1-a) d_{2}$.

A továbbiakban a következőképpen vizsgáljuk meg a hálózati struktúra szerepét! Induljunk ki egy olyan szimmetrikus struktúrából, ahol $a=0,5$ és $d_{1}=d_{2}=\bar{d}$ ! Ekkor a gazdaságban müködő vállalatok relatív fokszáma és gyakorisága is azonos. Kezdjük el növelni $a$ és ezzel párhuzamosan csökkenteni $d_{1}$ értékét, miközben $d_{2}$-t úgy

\footnotetext{
${ }^{8} \mathrm{~A} d_{1}$, illetve a $d_{2}$ paraméterek eredeti értelmezés szerint azt mutatják meg, hogy a szereplők mekkora hányada van kapcsolatban az egyes, illetve a kettes típusú vállalattal. Mivel azonban 1-re normáltuk a szereplők számát, vállalati fokszámként is tudjuk értelmezni ezeket a paramétereket.
} 
korrigáljuk, hogy a hálózati sűrűség konstans maradjon, vagyis a (16) összefüggés alapján $d_{2}=\bar{d} /(1-a)-a d_{1} /(1-a)$. Ezzel a hálózati struktúra fokozatosan eltolódik a szimmetrikus struktúrák felől az aszimmetrikus struktúrák irányába, ahol néhány nagy fokszámú szereplő mellett a többség relatíve kis fokszámmal rendelkezik. A skála végén, ahol $a \rightarrow 1$ és $d_{1} \rightarrow 0$, a hálózati struktúra erőteljesen centrális, és a gazdaságban müködő vállalatok zöme alacsony fokszámú, míg a vállalatok nagyon kis hányadának kimagaslóan nagy a fokszáma.

A 2. ábra a kibocsátás alakulását mutatja az imént definiált skála mentén. ${ }^{9}$ A folytonos fekete vonal azt az esetet mutatja, amikor a kétféle vállalattípus között a különbség azok gyakoriságában és fokszámában van, de technológiájuk azonos.

\section{2. ábra}

A kibocsátás alakulása a hálózati struktúra függvényében, konstans sűrűség mellett, különböző termelékenységi relációkra

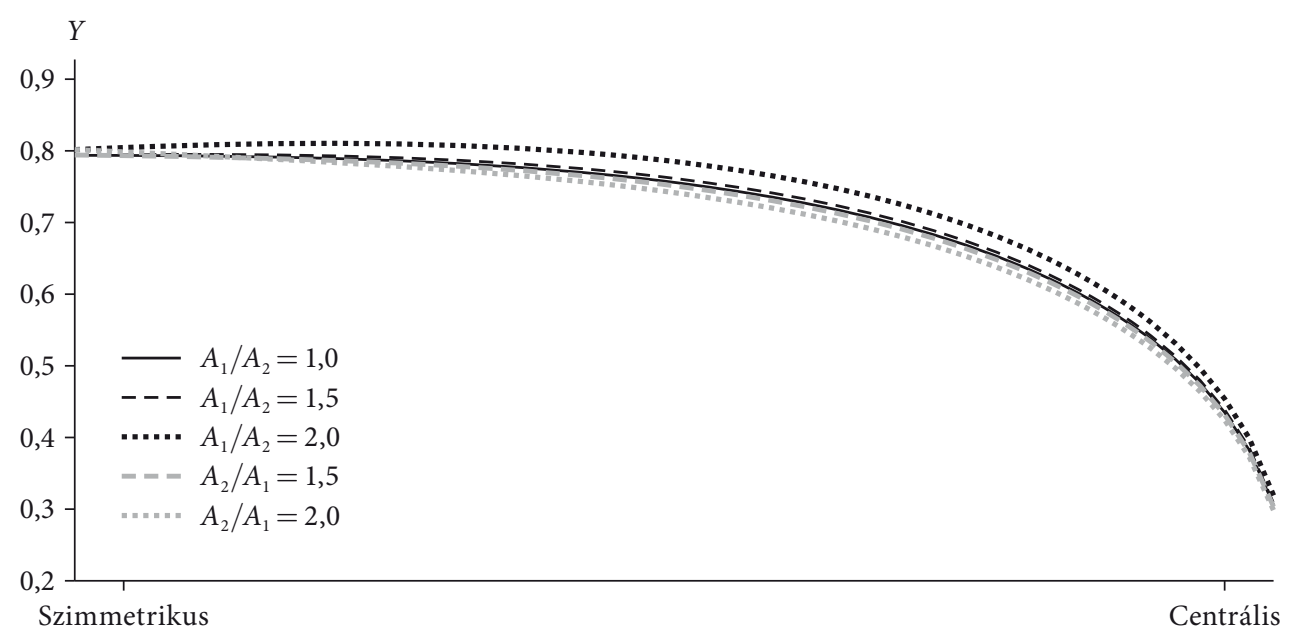

Jól látható, hogy a skála bal szélén lévő szimmetrikus hálózati szerkezetek lényegesen nagyobb kibocsátási szintet jelentenek, mint a jobb szélen található centralizált szerkezetek. Ez az eredmény összhangban van a modell korábban megfigyelt tulajdonságaival: a hálózati szerkezet nemteljessége holtteher-veszteséget generál. Ez a veszteség azonban nem pusztán a kapcsolatok hiányából, a sürüség csökkenéséből következik, hanem a kapcsolatok speciális elrendeződéséből is fakadhat. Az elosztottabb, szimmetrikus struktúra esetén a monopolhatások összességében gyengébbek, míg a szélsőségesen centrális esetben lényegesen erösebbek, hiszen itt azon túl, hogy átlagosan erösebb a monopolhelyzete a vállalatoknak a teljes kapcsoltsághoz képest, ez a monopolhelyzet koncentrálódik is a hálózatban központi szerepet betöltő vállalatoknál.

A 2. ábrán megvizsgáltuk azt is, hogy miben változik meg az iménti eredmény, ha a technológia homogenitására vonatkozó feltevést feloldjuk. Jól látszik, hogy amenynyiben az 1-es típusú vállalat technológiai előnyben van (ezen vállalatok aránya

\footnotetext{
${ }^{9}$ A paraméterekre a következő értékeket alkalmaztuk: $\bar{d}=1 / 2, \alpha=1 / 3$ és $\varepsilon=4$.
} 
csökken, a fokszáma pedig nő a vízszintes tengelyen jobbra haladva), ez a gazdaság aggregált kibocsátását a köztes hálózati szerkezetek mellett növeli. Vagyis azokban az esetekben, amikor a szerkezet már nem szimmetrikus, de nem is erősen centrális, a még viszonylag nagy számban jelen lévő 1-es típusú vállalatok technológiai előnye érezhető pozitív hatást gyakorol a kibocsátásra. Ahogy e vállalatok aránya kisebb lesz, ez a felhajtóerő eltűnik.

Ugyanígy, az 1-es típusú vállalatok technológiai hátránya szimmetrikusan csökkenti a kibocsátást a köztes hálózati szerkezetek mellett. Érdemes azt is megfigyelni, hogy ha az 1-es típusú vállalatok technológiai előnye elég magas, a köztes hálózati szerkezet nagyobb kibocsátást eredményez a szimmetrikus struktúrához képest. Vagyis a hálózati szerkezet centralizáltabbá válása (a szimmetrikus struktúrákhoz képest) a monopolhelyzetek erősítésén keresztül holtteher-veszteséget és csökkenő kibocsátást eredményez, ugyanakkor ezt ellensúlyozhatja az, ha az erősebb monopolhelyzetbe kerülő centrális vállalatok technológiai előnnyel rendelkeznek. Kicsit más interpretációban azt mondhatjuk, hogy a skálafüggetlen hálózati szerkezetet imitáló köztes struktúrák ebben a modellváltozatban előnyösebbek lehetnek a kiegyenlített szerkezetnél abban az esetben, ha a centrális vállalatok egyben hatékonyabb termelést is képesek megvalósítani.

Összefoglalva a kétféle vállalatot feltételező modell tanulságait, azt mondhatjuk, hogy a piaci információs hálózat struktúrája nem semleges a gazdaság aggregált müködésére nézve. A hálózati sủrüség mellett a hálózati struktúra szimmetriája egy másik olyan tényezö, amely pozitívan befolyásolja a gazdasági teljesítményt. Ugyanakkor azt is láttuk, hogy a gazdaságban müködő vállalatok termelékenységi adottságai megváltoztathatják a hálózati hatások mértékét, vagyis a hálózat szerepét a termelékenységi relációkkal együtt kell értékelni.

\section{Az általános eset}

Az előző modell fokszám és termelékenység tekintetében kétféle vállalatot feltételezett, most még tovább általánosítjuk a modellt, és felírjuk fokszám tekintetében tetszőleges számú vállalatra. Ezzel lehetőségünk nyílik különféle fokszám- és termelékenységeloszlások szerint vizsgálni a hálózat szerepét.

\section{Aggregált kibocsátás az általános esetben}

A kétféle típusú vállalatot feltételező modell levezetésénél alkalmazott logikát követve, felírhatjuk a modellt fokszám tekintetében tetszőleges számú vállalatra is. ${ }^{10}$

${ }^{10}$ Azonos logikát követve: fel tudjuk írni a bármely tetszőleges $j$-edik és $k$-adik vállalat egyensúlyi ára közötti összefüggést:

$$
p_{j, t}=\left(\frac{d_{k, t}}{d_{j, t}}\right)^{-\frac{\alpha}{1+\alpha(\varepsilon-1)}}\left(\frac{A_{k, t}}{A_{j, t}}\right)^{-\frac{1}{1+\alpha(\varepsilon-1)}} p_{k, t} .
$$

A levezetés többi lépése analóg a kétféle típusú vállalatot feltételező modellnél látottakkal. 
A különbség mindössze a $\widehat{c_{t}}$ kifejezésben lesz, amiben ezúttal tetszőleges elemszámú vektorok szerepelnek: ${ }^{11}$

$Y_{t}={\widehat{c_{t}}}^{\frac{1+\alpha(\varepsilon-1)}{\varepsilon-1}}$,

ahol

$\widehat{c_{t}}=\sum_{i=1}^{N_{t}} \frac{1}{d_{i, t}^{1+\alpha(\varepsilon-1)}} A_{i, t}^{\frac{\varepsilon-1}{1+\alpha(\varepsilon-1)}}$.

A modellben a $d_{i, t}$ hálózati paraméterek szerint tudjuk vizsgálni a hálózat szerepét, mindemellett lehetőségünk van a termelékenységbeli különbségek figyelembevételére is ( $A_{i, t}$ változók).

Mivel fokszám szempontjából tetszőleges számú különböző szereplőt tudunk modellezni, ebben az esetben már praktikusan fokszámeloszlásról beszélhetünk. Ez azért szerencsés, mert a hálózatelmélet eredményei alapján nem szükséges a hálózat összes lehetséges realizációját külön megvizsgálnunk, elegendő néhány, fokszámeloszlás alapján tipikusnak nevezhető hálózatra koncentrálnunk, hogy általános következtetéseket tudjunk felállítani. A következőkben a modell elemzése során a fokszámeloszlás szerepét külön és a termelékenységeloszlással együtt is megvizsgáljuk.

\section{A fokszámeloszlás szerepe}

A legtöbb valódi hálózatot skálafüggetlenség jellemzi, úgy is mondhatjuk, hogy a skálafüggetlenség a hálózatok természetes tulajdonsága (Barabási [2016]). Egy hálózatot akkor nevezünk skálafüggetlennek, ha jellemző rá a szélesfarkúság, vagyis a kiugróan sok kapcsolattal rendelkező csúcspontok jelenléte. Ugyanakkor nem triviális, milyen elvek alapján alakul ki a hálózati fokszámok ilyen alakú eloszlása. A hálózatokban a skálafüggetlenség kialakulását Barabási-Albert [1999] szerint két mechanizmus segíti: a növekedés és a preferenciális kapcsolódás.

A hálózatok növekedését Barabási [2016] alapján úgy tudjuk modellezni, ha kiindulunk egy $m$ elemű teljes hálózatból, majd mindig hozzáadunk a hálózathoz egy újabb csúcsot. Az új csúcs $m$ számú kapcsolatot hoz létre a már meglévő csúcsokkal a (19) valószínüségi modellnek megfelelően:

$\operatorname{Pr}\left(s_{i j}=1\right)=\frac{k_{j}^{\gamma}}{\sum_{n=1}^{i} k_{n}^{\gamma}}, j \leq i$,

ahol $i>m$ az új csúcs sorszáma, $k_{j}$ a $j \leq i$ meglevő csúcs fokszáma, $\operatorname{Pr}\left(s_{i j}=1\right)$ pedig annak valószínüsége, hogy az $i$-edik új csúcs a j-edik meglevő csúcshoz kapcsolódjon (vegyük észre, hogy a modell lehetővé teszi az önreflexív éleket is). A valószínűségi modellben a $\gamma$ paraméter határozza meg a kapcsolódási valószínűségeket, és ezzel befolyásolja a kialakuló hálózat fokszámeloszlásának alakját. Ha $\gamma=0$, az új csúcs ugyanakkora

\footnotetext{
${ }^{11}$ Mivel ebben a modellben akármennyi vállalatot meg tudunk jeleníteni, nincs szükségünk a továbbiakban az $a_{i, t}$ gyakorisági változók megkülönböztetésére.
} 
valószínűséggel kapcsolódik a meglévő csúcsok bármelyikéhez. Ez a kapcsolódási modell felel meg a véletlen hálózatnövekedési modellnek (lásd Erdős-Rényi [1959], [1960]). Ha $\gamma=1$, akkor a kapcsolódási valószínüségek arányosak a csúcs fokszámával, ebben az esetben az elöbb már említett preferenciális kapcsolódás elve müködik. Ekkor ugyanis az új csúcs nagyobb valószínűséggel fog olyan meglevő csúcshoz kapcsolódni, amely sok kapcsolattal rendelkezik. Az így kialakuló hálózat skálafüggetlen lesz. Ha $\gamma \rightarrow \infty$, akkor az új csúcs mindig az $m$ darab legnagyobb fokszámú csúcshoz fog kapcsolódni. Ekkor a kialakuló hálózat egy olyan csillaghálóra fog hasonlítani, amelyben van egy vagy több központi csúcs, amelyekhez az összes többi csúcs kapcsolódik. Meg kell jegyeznünk, hogy a hálózat növekedése miatt mindegyik esetben jellemző lesz a hálózatra az aszimmetria, hiszen a régebbi csúcsoknak több idejük van kapcsolatokat gyüjteni. A különbség a hálózatfejlődés következtében kialakuló fokszámeloszlás konkrét formájában van (exponenciális eloszlást kapunk a véletlen kapcsolódási modellnél, és hatványfüggvény-eloszlást a preferenciális kapcsolódás modelljénél).

A (19) hálózati modellben egy tetszőleges j-edik csúcs fokszámának időbeli változása arányos az adott csúcshoz való kapcsolódási valószínűséggel:

$\frac{\partial k_{j, t}}{\partial t}=m \frac{k_{j, t}^{\gamma}}{\sum_{n} k_{n, t}^{\gamma}}$.

Nézzük meg, miként alakul a fokszámok eloszlása és ettől függően a (18) hálózati konstans az egyes esetekben!

A VÉLETLEN KAPCSOLÓDÁSI MODELL • A fenti modellben a $\gamma=0$ feltevés a véletlen hálózatnövekedési modellt eredményezi, hiszen ekkor egy új csúcs ugyanakkora eséllyel kapcsolódik a meglevő csúcsok bármelyikéhez. Ekkor a (20) összefüggést a következőképpen írhatjuk fel:

$\frac{\partial k_{j, t}}{\partial t}=\frac{m}{t}$

ahol $t$ a létező csúcsok száma a vizsgált periódusban. Vagyis egy tetszőleges $j$-edik csúcs fokszáma $t$-ben: ${ }^{12}$

$k_{j, t}=m+\frac{m}{j+1}+\frac{m}{j+2}+\ldots+\frac{m}{t}=m(1+\ln t-\ln j)=m\left(1+\ln \frac{t}{j}\right)$.

A $k_{j, t}$ fokszámok segítségével fel tudjuk írni a (18) összefüggést a véletlen hálózatnövekedési modell esetén a következőképpen:

$\widehat{c_{t}}=\sum_{j=1}^{t}\left[\frac{m\left(1+\ln \frac{t}{j}\right)}{t}\right]^{\frac{1}{1+\alpha(\varepsilon-1)}} A_{j, t}^{\frac{\varepsilon-1}{1+\alpha(\varepsilon-1)}}=\left(\frac{m}{t}\right)^{\frac{1}{1+\alpha(\varepsilon-1)}} \sum_{j=1}^{t}\left(1+\ln \frac{t}{j}\right)^{\frac{1}{1+\alpha(\varepsilon-1)}} A_{j, t}^{\frac{\varepsilon-1}{1+\alpha(\varepsilon-1)}}$.

${ }^{12}$ Az összefüggésben kihasználtuk, hogy az n-edik harmonikus szám megközelítőleg megegyezik az $n$ természetes logaritmusával:

$\sum_{x=1}^{n} \frac{1}{x} \simeq \int_{1}^{n} \frac{1}{x} d x=\ln (n)$ 
A PREFERENCIÁLIS KAPCSOLÓDÁSI MODELL • Ha a hálózati modellben preferenciális kapcsolódást feltételezünk $(\gamma=1)$, akkor a fokszámok időbeli változására vonatkozó (20) összefüggés a következő lesz:

$\frac{\partial k_{j, t}}{\partial t}=m \frac{k_{j, t}}{2 t m}=\frac{k_{j, t}}{2 t}$,

ahol $2 \mathrm{tm}$ az egyedi fokszámok összege $t$-ben. ${ }^{13}$ Vagyis egy tetszőleges $j$-edik csúcs fokszáma $t$-ben: ${ }^{14}$

$k_{j, t}=m \sqrt{\frac{t}{j}}$.

Ekkor a (18) összefüggést felírhatjuk a következők szerint:

$\widehat{c_{t}}=\sum_{j=1}^{t}\left(\frac{m \sqrt{\frac{t}{j}}}{t}\right)^{\frac{1}{1+\alpha(\varepsilon-1)}} A_{j, t}^{\frac{\varepsilon-1}{1+\alpha(\varepsilon-1)}}=\left(\frac{m}{\sqrt{t}}\right)^{\frac{1}{1+\alpha(\varepsilon-1)}} \sum_{j=1}^{t} \sqrt{j}^{\frac{-1}{1+\alpha(\varepsilon-1)}} A_{j, t}^{\frac{\varepsilon-1}{1+\alpha(\varepsilon-1)}}$.

A SZÉLSŐSÉGESEN PREFERENCIÁLIS KAPCSOLÓDÁSI MODELL • Szélsőségesen preferenciális kapcsolódás esetén $\gamma \rightarrow \infty$, és a fokszámok időbeli alakulása a következőképpen néz ki:

$\frac{\partial k_{j, t}}{\partial t}= \begin{cases}m, & \text { ha } j=t \\ 1, & \text { ha } j \leq m \\ 0, & \text { különben. }\end{cases}$

Vagyis minden j-edik új csúcs az induló hálóban levő $m$ csúcsokhoz kapcsolódik. Ekkor a j-edik meglevő csúcs fokszámára igaz lesz:

$k_{j, t}= \begin{cases}t, & \text { ha } j \leq m \\ m, & \text { különben. }\end{cases}$

A (18) összefüggés ezek alapján a szélsőségesen preferenciális kapcsolódási modellben:

$$
\begin{aligned}
& \widehat{c_{t}}=\sum_{j=1}^{m} A_{j, t}^{\frac{\varepsilon-1}{1+\alpha(\varepsilon-1)}}+\sum_{j=m+1}^{t}\left(\frac{m}{t}\right)^{\frac{1}{1+\alpha(\varepsilon-1)}} A_{j, t}^{\frac{\varepsilon-1}{1+\alpha(\varepsilon-1)}}= \\
& =\sum_{j=1}^{m} A_{j, t}^{\frac{\varepsilon-1}{1+\alpha(\varepsilon-1)}}+\left(\frac{m}{t}\right)^{\frac{1}{1+\alpha(\varepsilon-1)}} \sum_{j=m+1}^{t} A_{j, t}^{\frac{\varepsilon-1}{1+\alpha(\varepsilon-1)}} .
\end{aligned}
$$

A 3. ábra a fokszámarányok $\left(d_{j, t}\right)$ alakulását mutatja be a három különböző hálózati modellben. Mindhárom hálózati modell esetében megfigyelhető, hogy

\footnotetext{
${ }^{13}$ Minden csúcspont $m$ kapcsolatot hoz létre, ez $t$-ben összesen $t m$ kapcsolat, és mivel egy kapcsolatot kétszer számolunk bele a fokszámokba, a fokszámok összege ennek kétszerese lesz.

${ }^{14}$ Az összefüggés levezetése a Függelékben szerepel.
} 
a fokszámarányok eloszlása aszimmetrikus, vagyis többségben vannak a relatíve alacsony fokszámú csúcspontok. Ugyancsak jellemző a hálózati modellek mindegyikére a szélesfarkúság is, vagyis a relatíve magas fokszámú csúcspontok jelenléte. Az egyes hálózati modellek közötti különbség ezeknek a mértékében van. Mind az eloszlás aszimmetriája, mind pedig a szélesfarkúsága a legextrémebben a szélsőségesen preferenciális modellnél mutatkozik meg, ezt követi a preferenciális, végül pedig a véletlen modell, bár a két utóbbi modellben a fokszámarányok alakulása nagyon hasonló egymáshoz (ezek között érezhetően nincs akkora különbség, mint a szélsőségesen preferenciális modellhez képest).

\section{3. ábra}

A fokszámarányok alakulása a véletlen, a preferenciális és a szélsőségesen preferenciális modellekben $(N=500, m=20)$

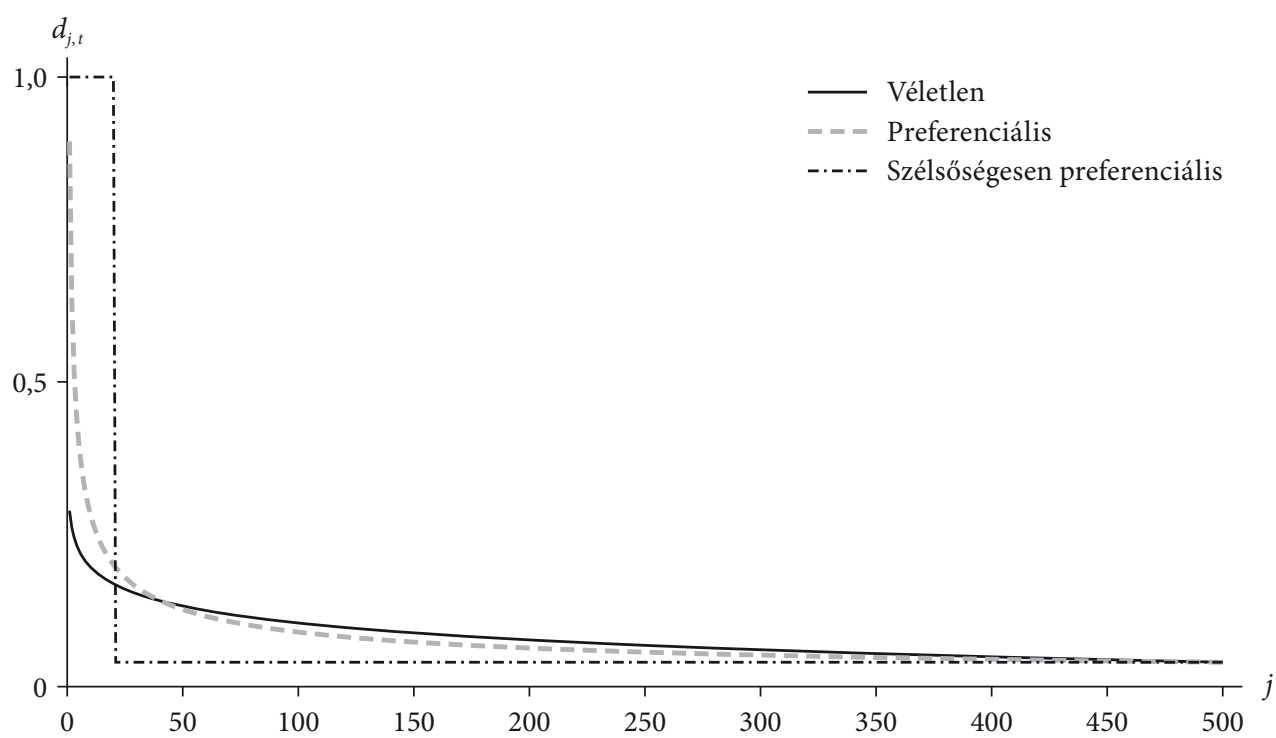

Most, hogy ismerjük a fokszámarányok alakulását az egyes modelleknél, vizsgáljuk meg, hogy miként alakul a kibocsátás a három kitüntetett hálózati modellben! A vizsgálatokban az 1. táblázatnak megfelelő értékeket használtuk. A 4. ábra a kibocsátás időbeli alakulását szemlélteti a különböző modellekben, a vállalatok homogén termelékenységét feltételezve. ${ }^{15}$

\footnotetext{
${ }^{15}$ Felmerül a kérdés, mi értelme van a szereplők számának folyamatos növekedését feltételezni, hiszen ez egy erösen irrealisztikus feltevés a piacokon. A szereplők számának növelése ebben az esetben mindössze azt a célt szolgálja, hogy ennek a hálózatnövekedési dinamikának a segítségével előállítsuk a különböző kapcsolódási modellekre jellemző fokszámeloszlásokat, amelyeket végül összehasonlítunk statikus és dinamikus szempontból is. Az összehasonlítás azért lehetséges, mert a szereplök száma időben konzisztens az egyes hálózati modellek között.
} 
1. táblázat

A vizsgálat során használt paraméterek jelölése, megnevezése és értéke

\begin{tabular}{llc}
\hline Jelölés & Elnevezés & Érték \\
\hline$N$ & A végső hálózat mérete & 500 \\
$m$ & Az induló hálózat mérete és az új kapcsolatok száma & 20 \\
$A_{j, t}$ & A termelékenységek vektora & $\forall j, t: 1$ \\
$\alpha$ & A munkaerőre vonatkozó termelési rugalmasság & $1 / 3$ \\
$\varepsilon$ & A termékek közötti helyettesítés rugalmassága & 4 \\
\hline
\end{tabular}

\section{4. ábra}

A kibocsátás időbeli alakulása a véletlen, a preferenciális és a szélsőségesen preferenciális hálózati modellekben $(N=500, m=20)$

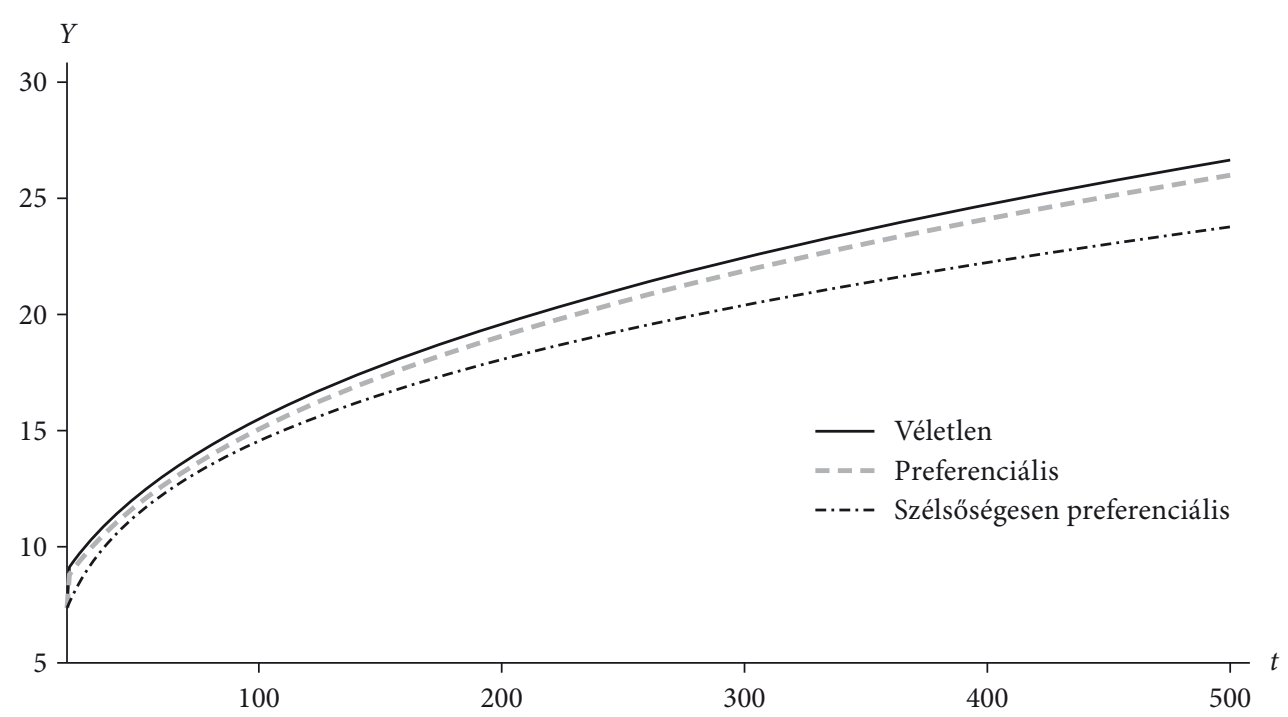

A három hálózati modell ugyanabból a teljes hálóból indul ki (a kezdő időszak kibocsátása megegyezik a modellekben), de az egyes modellek láthatóan már a növekedési folyamat elején különböznek egymástól a teljesítményükben. Az eredmények szerint minél erőteljesebben működik a preferenciális kapcsolódás a hálózati modellben, annál alacsonyabb hatékonyságú a kialakuló piaci hálózat, vagyis az eloszlás szélesfarkúságának és aszimmetriájának erősödése hatékonyságbeli veszteséget okoz. Ez az eredmény jól reflektál arra, amit a kétféle típusú vállalatot feltételező modellben láttunk, ahol konstans sürüség és homogén termelékenység mellett a struktúra aszimmetriája rontotta a makrogazdasági teljesítményt. Az is látszik, hogy hálózati modelltől függetlenül a hálózat növekedése pozitív trendet generál az aggregált kibocsátás szintjében. Ugyanakkor a növekedés üteme csökkenő. A hálózatok változásának marginális hatása a növekedési folyamat kezdeti szakaszában jelentősebb, majd egyre csökken a növekedés rátája. 
A növekedést alapvetően az okozza, hogy a hálózatformálódási folyamat során $\widehat{c_{t}}$, amely egyfajta speciális technológiai paraméterként viselkedik, növekszik. Ugyanakkor azt is láttuk korábban, hogy a $\widehat{c_{t}}$ növekedése mögött (a kapcsolódási sürüségek változásával párhuzamosan) a holtteher-veszteség csökkenése áll, vagyis a hálózatformálódás ezekben az esetekben egyfajta hatékonysági többlettel jár. A növekedés csökkenő üteme magyarázható azzal, hogy a hálózatformálódási modellek jellegéből fakadóan a kapcsolatok száma idővel lineárisan nő (minden időszakban azonos számú új kapcsolat lép be a hálózatba), ugyanakkor a lehetséges kapcsolatok száma - amely a $\widehat{c_{t}}$ paraméter mögötti sürüségeket befolyásolja - négyzetesen növekszik.

A hálózati modellek az elérhető növekedési ütem szintjében is különböznek: a véletlen modell eredményezi a legmagasabb ütemű gazdasági növekedést, ezt követi minimális hatékonyságkülönbséggel a preferenciális modell, míg a szélsőségesen preferenciális modell mellett a legalacsonyabb ütemű a gazdasági növekedés. Vagyis a hálózati modellben a kapcsolódás erőssége mind a kibocsátás nagyságát, mind annak növekedési ütemét negatívan befolyásolja, de a kapcsolat nem lineáris. A véletlen és a preferenciális kapcsolódási modell hatékonysága között érezhetően nincs akkora különbség, mint a preferenciális és a szélsőségesen preferenciális kapcsolódási modellek között. Vagyis az eredmények a fokszámarányok esetén látott tendenciákat tükrözik vissza, ahol azt láttuk, hogy a véletlen és a preferenciális kapcsolódási modellek nagyon hasonlók a fokszámok tekintetében, míg a szélsőségesen preferenciális kapcsolódási modellben a fokszámok eloszlása erőteljesen aszimmetrikus (lásd 3. ábra).

Az 5. ábrán azzal egészítjük ki az iménti dinamikus vizsgálatot, hogy nem csupán a három kitüntetett hálózati modell $(\gamma \in\{0 ; 1 / 2 ; 1\})$ mellett, hanem a modellek egy széles skáláján mutatjuk be a kibocsátás alakulását, azonban az áttekinthetőség kedvéért csak a vizsgált időszak végén (tehát az 500. periódusban). Az ábra elkészítéséhez szimulációt végeztünk a (20) hálózati modellel, bevezetve az $r=\gamma /(1+\gamma)$ jelölést. Ekkor ugyanis az $r$ paraméter segítségével egy 0 és 1 közötti skálán tudjuk reprezentálni a hálózatokat, ahol a skála elején $(r=0)$ találjuk a véletlen, a skála közepén $(r=1 / 2)$ a preferenciális, míg a skála végén $(r \approx 1)$ a szélsőségesen preferenciális hálózati modellt. Az $r$ értékét lépésekben növelve 0-ról 1-re, 100 szimulációt végeztünk el minden érték mellett, és ezek átlagát mutatjuk be az 5. ábrán, ezzel kiszürve a hálózati modellből eredő sztochasztikus hatásokat.

Az eredmények azt mutatják, hogy a hálózat centralitásának növekedésével a gazdaság aggregált teljesítménye csökken: a legmagasabb kibocsátást a szimmetrikus, a legalacsonyabb kibocsátást a szélsőségesen centrális szerkezetek mellett kapjuk, ugyanakkor ez az átmenet nem lineáris: a preferenciális kapcsolódást jelentő $r=0,5$ esetben alig valamivel kisebb a kibocsátás, mint a preferenciális elemet nem tartalmazó modellnél, majd ezt követően egy hirtelen esés következik a centrális szerkezetek felé haladva a kibocsátásban.

Összefoglalva az eredményeket, azt látjuk, hogy a hálózat növekedése pozitív trendet generál a kibocsátásban, ugyanakkor a gazdaság a hálózatformálódási modelltől függően eltérő növekedési ütemet tud elérni. Az eddigi elemzéseknél homogén és konstans technológiát feltételeztünk. Annak érdekében, hogy a termelékenységbeli különbségek szerepét is vizsgálni tudjuk, a következőkben bekapcsoljuk az elemzésbe a termelékenységeloszlást is. 


\section{5. ábra}

A hálózat centralitását meghatározó paraméter hatása a kibocsátásra $(Y)$

[A vizsgált időszak végén $(t=500), r=0$ felel meg a véletlen, $r=0,5$ a preferenciális, míg $r \approx 1$ a szélsőségesen preferenciális hálózati modellnek]

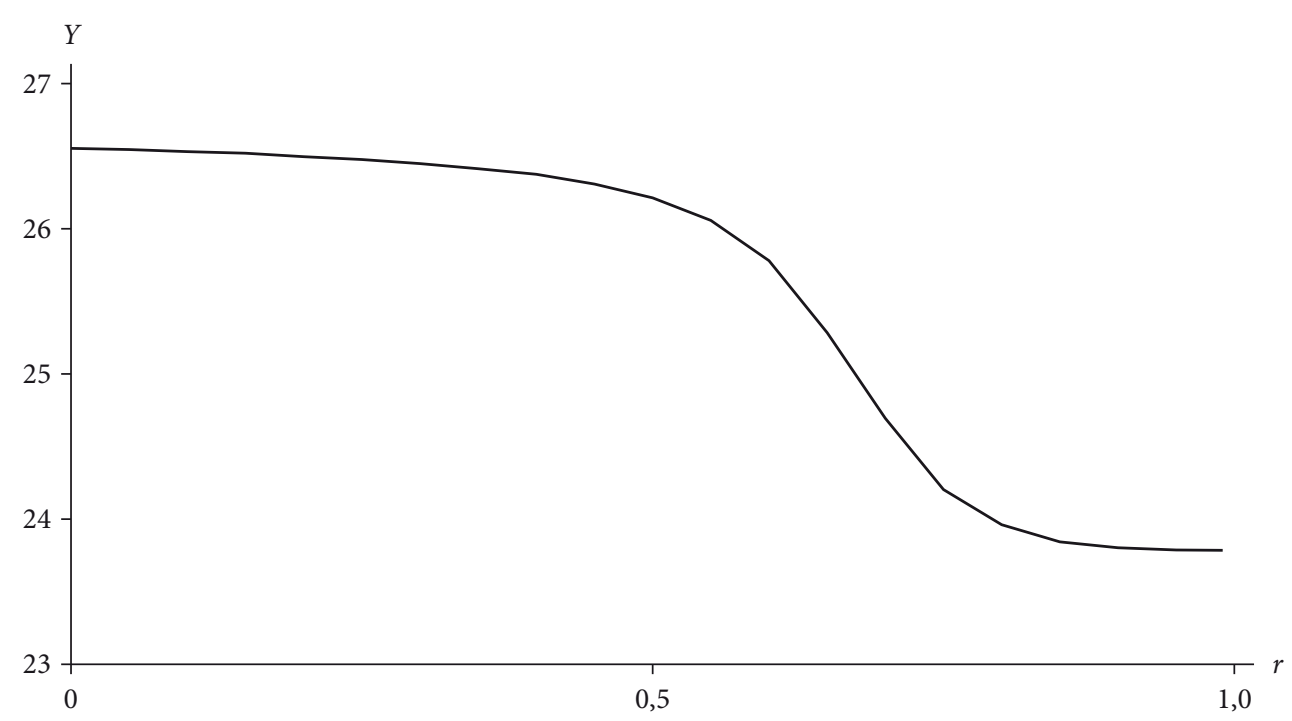

A fokszám-és a termelékenységeloszlás együttes szerepe

Eddig a vállalatok termelékenységét egyformának tekintettük. Most szakítunk a homogén technológia feltevésével, és heterogén termelékenységü vállalatokat feltételezünk. Ez azért lehet érdekes kérdés, mert a kétvállalatos modellnél már láttuk, hogy a vállalatok termelékenységi relációja megváltoztathatja a hálózati struktúra hatékonyságát. Ezúttal azonban a termelékenységek eloszlását vizsgáljuk, vagyis sokkal általánosabb következtetéseket tudunk levonni. Vizsgáljuk a továbbiakban a következő három technológiai rezsimet:

1. homogén technológia: $A_{i, t}=1$,

2. szimmetrikus technológia: $A_{i, t} \sim \mathcal{N}(1,0,1)$,

3. korrelált technológia: $A_{i, t} \sim \mathcal{N}(1,0,1) \mid \forall i, j: d_{i, t}>d_{j, t} \Rightarrow A_{i, t}>A_{j, t}$.

A homogén technológiai rezsim felel meg az eddigi vizsgálatainknak, ez a továbbiakban benchmarkként szolgál. Szimmetrikus technológiai rezsim esetén a termelékenységeket 1 várható értékű és 0,1 szórású normális eloszlásból származtatjuk. Korrelált technológiai rezsim esetén a szimmetrikus rezsimnek megfelelően származtatjuk az értékeket, de a termelékenységek vektorát úgy permutáljuk, hogy a legnagyobb fokszámú vállalat legyen egyben a legtermelékenyebb is. Ez utóbbi esetben tehát a vállalatok fokszáma és termelékenysége tökéletesen korrelál egymással. Az összehasonlíthatóság érdekében a termelékenységek várható értéke mindhárom rezsim esetén 1.

A 4. ábrán láttuk, hogy a három kitüntetett hálózati modell mellett milyen pályát ír le a kibocsátás, feltéve, hogy a vállalatok technológiai szintje homogén. A 6. ábra azt 
mutatja, hogy milyen eltéréseket tapasztalunk ettől az alapesettől (továbbra is a három kitüntetett hálózati modell mellett), ha a technológia a fenti definícióknak megfelelően heterogén, de szimmetrikus, illetve heterogén, de korrelál a fokszámokkal.

6. ábra

A kibocsátás százalékos eltérése szimmetrikus és korrelált technológia esetén a homogén technológiához képest, különböző hálózati modellekben

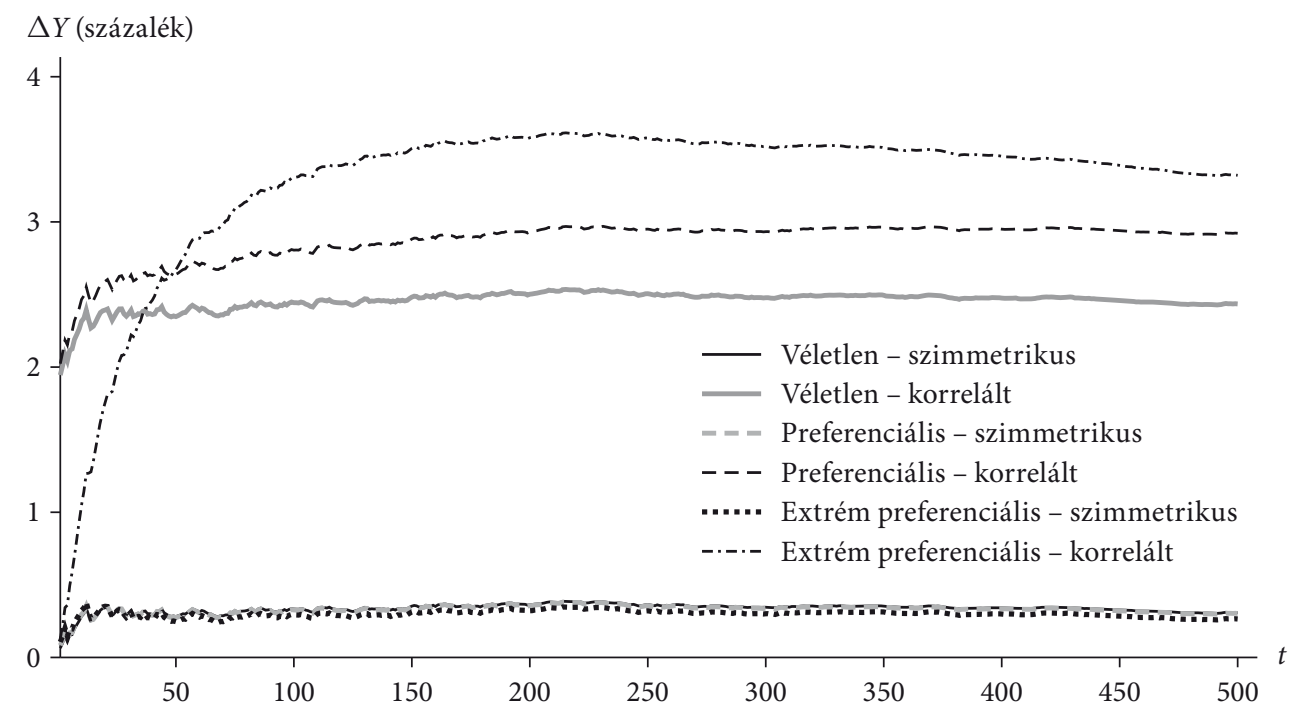

Elöször is az látszik, hogy a heterogén, de szimmetrikus esetben kismértékben (körülbelül 0,25 százalékkal) magasabb kibocsátási pályát fut be a gazdaság, mint a homogén esetben, a hálózati szerkezet szerepe itt nem látszik relevánsnak. Ugyanakkor hosszú távon jelentős, 2,5-3,5 százalékkal magasabb pályán mozog a kibocsátás, ha a technológiai szintek korrelálnak a fokszámokkal, vagyis jellemzö, hogy a nagyobb fokszámú, így erősebb monopolhelyzetben lévő vállalatok egyben hatékonyabbak is. Ez egybevág a két vállalattípus mellett végzett elemzésekkel, ahol szintén azt tapasztaltuk, hogy pozitív hatása van a kibocsátásra annak, ha a centrálisabb szereplők egyben termelékenyebbek is.

Másodszor az is látszik, hogy a fokszámmal korreláló technológiai rezsim esetén a hálózati modell is meghatározó a kibocsátás alakulásában. Minél centralizáltabb struktúrát nézünk, annál nagyobb pozitív irányú eltérést látunk a hosszú távú kibocsátásban a homogén technológiához képest. Ezt a jelenséget az magyarázhatja, hogy a technológiai szint korreláltsága a fokszámmal alapvetően akkor érvényesül, amikor a hálózat szerkezete elegendően aszimmetrikus ahhoz, hogy a nagyobb fokszámú szereplők monopolereje domináns legyen. Minél centralizáltabb egy hálózat, ennek megfelelően annál nagyobb „felhajtóerőt” biztosít a kibocsátásban a fokszámhoz (centralitáshoz) kapcsolódó technológiai szint vagy hatékonysági előny.

A most bemutatott eredmények a piaci hálózat szerepét általánosságban jellemzik. Korábban már láttuk, hogy a piaci hálózat tökéletlensége holtteher-veszteséget 
okoz. Most már az is látszik, hogy ez a holtteher-veszteség nemcsak a hálózat sürüségével és szimmetriájával van kapcsolatban, hanem függ a fokszámok eloszlásának struktúrájától és a termelékenységi viszonyoktól is.

\section{Összefoglalás}

A tanulmányban hálózati megközelítéssel modelleztük a piaci szereplök nem teljes informáltságát: egy olyan modellt ismertettünk, amelyben az információk elérhetőségét a hálózati kapcsolatok határozták meg. A piaci hálózat nemteljessége azt eredményezte, hogy a termelés a hálózati struktúra által meghatározottá vált. A szereplők nem teljes informáltsága aggregált szinten holtteher-veszteséget okoz, ami a ritkuló piaci kapcsolatok által generált, pótlólagos monopolizációból ered. A hálózat ritkulása - és ugyanígy a hálózati struktúra centrálisabbá válása - növeli ennek a holtteher-veszteségnek a mértékét. A magas sürűségü és szimmetrikus információs struktúra teszi a leghatékonyabbá a gazdaság müködését, ha a termelők technológiai szintje homogén. Ha azonban a hálózatban betöltött centrális szereppel együtt termelékenységi előny is jár, a domináns, erősebb monopolhelyzetben lévő vállalatok ilyen hatékonysági előnye pozitív hatással van a kibocsátásra: a kiegyensúlyozott hálózati struktúrához képest nagyobb kibocsátást képes generálni az aszimmetrikus topológia, ha összefügg egymással a technológiai szint és a hálózati pozíció.

Általánosságban tehát azt mutattuk meg, hogy a gazdaság szereplöit összekötő információs/piaci hálózat szerkezete érdemi hatást gyakorol a gazdaság aggregált teljesítményére, és ez a hatás nem független a piaci szereplők termelékenységétöl. A bemutatott modellkeretben további izgalmas kutatási kérdés lehet a hálózati struktúra aszimptotikus tulajdonságainak és a holtteher-veszteség-jólét kapcsolatának a vizsgálata, illetve exogén hálózati struktúra helyett a szereplők döntései alapján formálódó hálózatok feltételezése.

\section{Hivatkozások}

Angeletos, G.-M.-Lian, C. [2016]: Incomplete Information in Macroeconomics: Accommodating Frictions in Coordination. Megjelent: Taylor, B.-Uhlig, H. (szerk): Handbook of Macroeconomics. Vol. 2. North Holland, Amszterdam, 1065-1240. o. https://doi.org/10.1016/bs. hesmac.2016.04.011.

Arrow, K. J.-Debreu, G. [1954]: Existence of an equilibrium for a competitive economy. Econometrica, Vol. 22. No. 3. 265-290. o. https://doi.org/10.2307/1907353.

BaLA, V.-Goyal, S. [2000]: A Noncoperative Model of Network Formation. Econometrica, Vol. 68. No. 5. 1181-1229. o. https://doi.org/10.1111/1468-0262.00155.

Barabási Albert-László [2016]: A hálózatok tudománya. Libri Kiadó, Budapest.

Barabási Albert-LÁszló-Albert RéKa [1999]: Emergence of Scaling in Random Networks. Science, Vol. 286. No. 5439. 509-512. o. https://doi.org/10.1126/science.286.5439.509.

BARro, R. [1976]: Rational Expectations and the Role of Monetary Policy. Journal of Monetary Economics, Vol. 2. No. 1. 1-32. o. https://doi.org/10.1016/0304-3932(76)90002-7. 
Benassy, J. P. [1996]: Taste for variety and optimum production patterns in monopolistic competition. Economics Letters, Vol. 52. No. 1. 41-47. o. https://doi.org/10.1016/01651765(96)00834-8.

Csermely Péter [2005]: A rejtett hálózatok ereje. Mi segíti a világ stabilitását? Vince Kiadó, Budapest.

Dixit, A. K.-Stiglitz, J. E. [1977]: Monopolistic Competition and Optimum Product Diversity. The American Economic Review, Vol. 67. No. 3. 297-308. o.

Erdős Pál-Rényi Alfréd [1959]: On Random Graphs. Publicationes Mathematicae, Vol. 6. 290-297. o.

Erdős PÁL-RÉnyi Alfréd [1960]: On the Evolution of Random Graphs. Hungarian Academy of Sciences Institute of Mathematics, Vol. 5. 17-61. o.

GaLI, J. [2008]: Monetary Policy, Inflation and the Business Cycle. An Introduction to the New Keynesian Framework. Princeton University Press, Princeton.

Granovetter, M. [1973]: The Strength of Weak Ties. American Journal of Sociology, Vol. 78. No. 6. 1360-1380. o. https://doi.org/10.1086/225469.

Granovetter, M. [1985]: Economic Action and Social Sturcture: The Problem of Embeddedness. American Journal of Sociology, Vol. 91. No. 3. 481-510. o. https://doi.org/ $10.1086 / 228311$.

Hayek, F. A. [1945]: The Use of Knowledge in Society. American Economic Review, Vol. 35. No. 4. 519-530. o.

Jackson, M.-Wolinsky, A. [1996]: A Strategic Model of Social and Economic Networks. Journal of Economic Theory, Vol. 71. No. 1.44-74. o. https://doi.org/10.1006/jeth.1996.0108.

L'Huillier, J. P. [2012]: Consumers' Imperfect Information and Price Rigidities. Einaudi Institute for Economics and Finance, EIEF Working Papers Series, No. 1209.

LucAs, R. E. [1972]: Expectations and the Neutrality of Money. Journal of Economic Theory, Vol. 4. No. 2. 103-124. o. https://doi.org/10.1016/0022-0531(72)90142-1.

LucAs, R. E. [1973]: Some International Evidence on Output-Inflation Tradeoffs. American Economic Review, Vol. 63. No. 3. 326-334. o.

Lucas, R. E. [1975]: An Equilibrium Model of the Business Cycle. Journal of Political Economy, Vol. 83. No. 6. 1113-1144. o. https://doi.org/10.1086/260386.

Marvel, H. P. [1976]: The Economics of Information and Retail Gasoline Price Behavior: An Empirical Analysis. Journal of Political Economy, Vol. 84. No. 5. 1033-1060. o. https:// doi.org/10.1086/260495.

Mankiw, N. G.-Reis, R. [2002]: Sticky information versus sticky prices: A proposal to replace the new Keynesian Phillips curve. Quarterly Journal of Economics, Vol. 117. No. 4. 1295-1328. o. https://doi.org/10.1162/003355302320935034.

Mankiw, N. G.-Reis, R. [2010]: Imperfect Information and Aggregate Supply. Megjelent: Friedman, B. M.-Woodford, M. (szerk.): Handbook of Monetary Economics. North Holland, Amszterdam, 183-229. o. https://doi.org/10.1016/b978-0-444-53238-1.00005-3.

Mérő LÁszló [2014]: A csodák logikája. A kiszámíthatatlan tudománya. Tericum Kiadó, Budapest.

Phelps, E. S. [1970]: Microeconomic Foundations of Employment and Inflation Theory. W. W. Norton, New York.

ReIs, R. [2006a]: Inattentive Producers. Review of Economic Studies, Vol. 73. No. 3. 793-821. o. https://doi.org/10.1111/j.1467-937x.2006.00396.x.

ReIs, R. [2006b]: Inattentive Consumers. Journal of Monetary Economics, Vol. 53. No. 8. 1761-1800. o. https://doi.org/10.1016/j.jmoneco.2006.03.001. 
Sims, C. A. [2003]: Implications of rational inattention. Journal of Monetary Economics, Vol. 50. No. 3. 665-690. o. https://doi.org/10.1016/s0304-3932(03)00029-1.

Sims, C. A. [2010]: Rational Inattention and Monetary Economics. Megjelent: Friedman, B. M.-Woodford, M. (szerk.): Handbook of Monetary Economics. North Holland, Amszterdam, 155-181. o. https://doi.org/10.1016/b978-0-444-53238-1.00004-1.

Stigler, G. J. [1961]: The Economics of Information. The Journal of Political Economy, Vol. 69. No. 3. 213-225. o. https://doi.org/10.1086/258464.

Townsend, R. [1983]: Forecasting the Forecasts of Others. Journal of Political Economy, Vol. 91. No. 4. 546-588. o. https://doi.org/10.1086/261166.

Woodford, M. [2002]: Imperfect Common Knowledge and the Effects of Monetary Policy, in Knowledge, Information, and Expectations in Modern Macroeconomics. Megjelent: Aghion, P.-Frydman, R.-Stiglitz, J.-Woodford, M. (szerk.): Honor of Edmund S. Phelps. Princeton University Press, Princeton, 25-58. o.

\section{Függelék}

\section{Háztartások keresleti függvénye}

A feladathoz tartozó Lagrange-függvény és az elsőrendü deriváltak:

$$
\begin{aligned}
& L_{i, t}\left(c_{i j, t}, \lambda_{i, t}\right)=\left(\sum_{j=1}^{N_{t}} s_{i j, t} c_{i j, t}^{\frac{\varepsilon-1}{\varepsilon}}\right)^{\frac{\varepsilon}{\varepsilon-1}}-\lambda_{i, t}\left(z_{i, t}-\sum_{j=1}^{N_{t}} p_{j, t} c_{i j, t}\right), \\
& \frac{\partial L_{i, t}}{\partial c_{i j, t}}=\frac{\varepsilon}{\varepsilon-1}\left(\sum_{j=1}^{N_{t}} s_{i j, t} c_{i j, t} \frac{\varepsilon-1}{\varepsilon}\right)^{\frac{\varepsilon}{\varepsilon-1}-1} \frac{\varepsilon-1}{\varepsilon} s_{i j, t} c_{i j, t}^{\frac{\varepsilon-1}{\varepsilon}-1}-\lambda_{i, t} p_{j, t}=0 j=1, \ldots, N_{t}, \\
& \frac{\partial L_{i, t}}{\partial \lambda_{i, t}}=z_{i, t}-\sum_{j=1}^{N_{t}} p_{j, t} c_{i j, t}=0 .
\end{aligned}
$$

Az első elsőrendü feltétel alapján:

$c_{i j, t}=s_{i j, t}^{\varepsilon} C_{i, t}\left(\lambda_{i, t} p_{j, t}\right)^{-\varepsilon}$.

Vegyünk egy olyan $k$-adik vállalatot, amelyre $s_{i k, t} \neq 0$, és osszuk el a két vállalat terméke iránti keresleteket:

$c_{i j, t}=\left(\frac{s_{i j, t}}{s_{i k, t}}\right)^{\varepsilon}\left(\frac{p_{j, t}}{p_{k, t}}\right)^{-\varepsilon} c_{i k, t}$.

Helyettesítsük vissza ezt a második elsőrendü feltételbe:

$z_{i, t}=\sum_{j=1}^{N_{t}} p_{j, t} c_{i j, t}=\sum_{j=1}^{N_{t}} p_{j, t}\left(\frac{s_{i j, t}}{s_{i k, t}}\right)^{\varepsilon}\left(\frac{p_{j, t}}{p_{k, t}}\right)^{-\varepsilon} c_{i k, t}=s_{i k, t}^{-\varepsilon} p_{k, t}^{\varepsilon} c_{i k, t} \sum_{j=1}^{N_{t}} s_{i j, t}^{\varepsilon} p_{j, t}^{1-\varepsilon}$.

Legyen az $i$-edik háztartásra vonatkozó árindex a következő: 
$P_{i, t}^{H}=\left(\sum_{j=1}^{N_{t}} s_{i j, t}^{\varepsilon} p_{j, t}^{1-\varepsilon}\right)^{\frac{1}{1-\varepsilon}}$.

Ekkor az előbbi összefüggést fel tudjuk írni az alábbiak szerint:

$z_{i, t}=s_{i k, t}^{-\varepsilon} p_{k, t}^{\varepsilon} c_{i k, t} P_{i, t}^{H^{1-\varepsilon}}$,

amiből:

$c_{i k, t}=s_{i k, t}^{\varepsilon} p_{k, t}^{-\varepsilon} z_{i, t} P_{i, t}^{H^{\varepsilon-1}}$.

A célfüggvény értéke optimumban:

$$
\begin{aligned}
& C_{i, t}=\left[\sum_{j=1}^{N_{t}} s_{i j, t}\left(s_{i j, t}^{\varepsilon} p_{j, t}^{-\varepsilon} z_{i, t} P_{i, t}^{H^{\varepsilon-1}}\right)^{\frac{\varepsilon-1}{\varepsilon}}\right]^{\frac{\varepsilon}{\varepsilon-1}}=z_{i, t} P_{i, t}^{H^{\varepsilon-1}}\left(\sum_{j=1}^{N_{t}} s_{i j, t}^{\varepsilon} p_{j, t}^{1-\varepsilon}\right)^{\frac{\varepsilon}{\varepsilon-1}}= \\
& =z_{i, t} P_{i, t}^{H^{\varepsilon-1}}\left(P_{i, t}^{H^{1-\varepsilon}}\right)^{\frac{\varepsilon}{\varepsilon-1}}=\frac{z_{i, t}}{P_{i, t}^{H}} .
\end{aligned}
$$

Ezek szerint optimális döntés esetén:

$z_{i, t}=P_{i, t}^{H} C_{i, t}$.

Ezt felhasználva, a háztartás $k$-adik termék iránti kereslete kifejezhető a termék ára, a háztartás kompozit fogyasztása és a rá vonatkozó árindex segítségével:

$c_{i k, t}=s_{i k, t}^{\varepsilon} C_{i, t}\left(\frac{p_{k, t}}{P_{i, t}^{H}}\right)^{-\varepsilon}$,

ahol

$P_{i, t}^{H}=\left(\sum_{j=1}^{N_{t}} s_{i j, t}^{\varepsilon} p_{j, t}^{1-\varepsilon}\right)^{\frac{1}{1-\varepsilon}}$.

Ha a kapcsolatok binárisak, akkor az $s_{i j, t}$ hálózati kapcsolatok 0 és 1 értékeket vehetnek fel, és a keresleti függvény leegyszerüsödik:

$c_{i k, t}=s_{i k, t} C_{i, t}\left(\frac{p_{k, t}}{P_{i, t}^{H}}\right)^{-\varepsilon}$,

ahol

$P_{i, t}^{H}=\left(\sum_{j=1}^{N_{t}} s_{i j, t} p_{j, t}^{1-\varepsilon}\right)^{\frac{1}{1-\varepsilon}}$.

\section{Vállalatok egyensúlyi ára}

A feltételi függvényt behelyettesítve a célfüggvénybe, kapjuk:

$$
\max _{p_{j, t}} \Pi_{j, t}=p_{j, t}^{1-\varepsilon} \sum_{i=1}^{N_{t}} s_{i j, t} C_{i, t} P_{i, t}^{H^{\varepsilon}}-T C_{j, t}\left(p_{j, t}^{-\varepsilon} \sum_{i=1}^{N_{t}} s_{i j, t} C_{i, t} P_{i, t}^{H^{\varepsilon}}\right) .
$$


A döntési változó szerinti elsőrendű parciális derivált a következő lesz:

$$
\begin{aligned}
& \frac{\partial \Pi_{j, t}}{\partial p_{j, t}}=(1-\varepsilon) p_{j, t}^{-\varepsilon} \sum_{i=1}^{N_{t}} s_{i j, t} C_{i, t} P_{i, t}^{H^{\varepsilon}}-\frac{\partial T C_{j, t}\left(y_{j, t}\right)}{\partial y_{j, t}}(-\varepsilon) p_{j, t}^{-\varepsilon-1} \sum_{i=1}^{N_{t}} s_{i j, t} C_{i, t} P_{i, t}^{H^{\varepsilon}}= \\
& =p_{j, t}-\frac{\varepsilon}{\varepsilon-1} M C_{j, t}=0,
\end{aligned}
$$
ahol kihasználtuk, hogy $\frac{\partial T C_{j, t}\left(y_{j, t}\right)}{\partial y_{j, t}}=M C_{j, t}$. Ez alapján a j-edik vállalat opti-
mális ára:

$p_{j, t}=\frac{\varepsilon}{\varepsilon-1} M C_{j, t}$.

\section{A fokszámok időbeli alakulása a preferenciális kapcsolódási modellben}

A fokszámok alakulását leíró összefüggést megkapjuk, ha megoldjuk a következő differenciálegyenlet-rendszert:

$\frac{d k_{j, t}}{d t}=\frac{k_{j, t}}{2 t}$

$k_{j, j}=m$,

ahol az utóbbi feltétel azt mondja ki, hogy minden csúcspont $m$ kapcsolatot hoz létre, amikor létrejön. A megoldás lépései:

$2 \int \frac{1}{k_{j, t}} d k_{j, t}=\int \frac{1}{t} d t$

$2 \ln k_{j, t}=\ln t+C$,

$\ln k_{j, t}^{2}=\ln t+C$.

Mivel $\ln k_{j, j}^{2}=\ln j+C$, ezért a második feltétel értelmében $\ln m^{2}=\ln j+C$. Ezt visszahelyettesítve a legutóbbi összefüggésbe:

$\ln k_{j, t}^{2}=\ln t+\ln m^{2}-\ln j$.

Végül elvégezve a szükséges átalakításokat, megkapjuk a keresett összefüggést:

$k_{j, t}=m \sqrt{\frac{t}{j}}$. 